\title{
Biological removal of phosphorus from wastewater
}

\author{
Arvin, Erik
}

Published in:

Critical Reviews in Environmental Control

Publication date:

1985

Document Version

Early version, also known as pre-print

Link back to DTU Orbit

Citation (APA):

Arvin, E. (1985). Biological removal of phosphorus from wastewater. Critical Reviews in Environmental Control, $15(1), 25-64$.

\section{General rights}

Copyright and moral rights for the publications made accessible in the public portal are retained by the authors and/or other copyright owners and it is a condition of accessing publications that users recognise and abide by the legal requirements associated with these rights.

- Users may download and print one copy of any publication from the public portal for the purpose of private study or research.

- You may not further distribute the material or use it for any profit-making activity or commercial gain

- You may freely distribute the URL identifying the publication in the public portal

If you believe that this document breaches copyright please contact us providing details, and we will remove access to the work immediately and investigate your claim 


\title{
BIOLOGICAL REMOVAL OF PHOSPHORUS FROM WASTEWATER
}

\author{
Author: Erik Arvin \\ Department of Environmental \\ Engineering \\ Technical University of Denmark \\ Lyngby, Denmark \\ Referee: David Jenkins \\ Department of Civil Engineering \\ University of California \\ Berkeley, California
}

\section{INTRODUCTION}

Phosphorus (P) removal from wastewater is most often performed in order to prevent or reduce eutrofication. This phenomenon of extensive algae growth has developed in many countries from being mostly an aesthetic and recreational problem to a significant economical problem. In many water-treatment plants based on surface water, the consumption of coagulants has increased significantly in order to maintain low levels of organic, taste, odor, and color substances in the finished drinking water. While impairment of fisheries in lakes and fiords has been known for several decades, similar problems have lately been observed in coastal areas.

By removing $\mathbf{P}$ from wastewater, this substance may eventually be the algae growth determining factor in surface water. Another reason to remove $\mathbf{P}$ is that it may be competitive in price compared to inorganic $P$ fertilizers. ${ }^{1}$ The requirement is, of course, that treatment costs are relatively low. In this respect, biological $\mathrm{P}$ removal is particularly interesting. This treatment technology is characterized by the use of microorganisms to remove $\mathbf{P}$ to low effluent concentrations. Accordingly, costs of precipitation chemicals can be saved or reduced significantly. The additional sludge production from adding chemicals can also be avoided.

\section{TREATMENT PROCESSES}

So far biological $\mathrm{P}$ removal has only been observed in activated sludge plants. Future developments, however, may also lead to biological $\mathrm{P}$ removal in fixed film systems or combinations of fixed film and suspended growth systems. The principal process differences will be outlined in the following.

\section{A. Principal Process Differences}

Biological $P$ removal processes are either sidestream processes or mainstream processes. This is illustrated in Figure 1. Mainstream processes are characterized by the removal of $P$ together with the surplus sludge. $P$ uptake and storage occur in the mainstream. In sidestream processes, $\mathrm{P}$ is extracted from the sludge in a sidestream, which is small compared to the mainstream ( 5 to $25 \%$ ). The extracted phosphate is subsequently precipitated with lime to form calcium phosphate. This process type combines biological extraction and concentration and subsequent chemical fixation of $P$.

For the purpose of illustration, the assumed flows and concentrations are indicated in Figure 1. The influent total $P$ concentration of $9 \mathrm{mg}$ of $\mathrm{P}$ per liter is reduced to 1 $\mathrm{mg}$ of $\mathrm{P}$ per liter. The surplus sludge production is in both cases $120 \mathrm{mg} / \ell$ of influent wastewater $\left(\mathrm{BOD}_{5}=240 \mathrm{mg} / \ell\right.$, observed yield constant, $\left.\mathrm{Y}_{o b s}=0.5\right)$. 
MAINSTREAM PROCESS

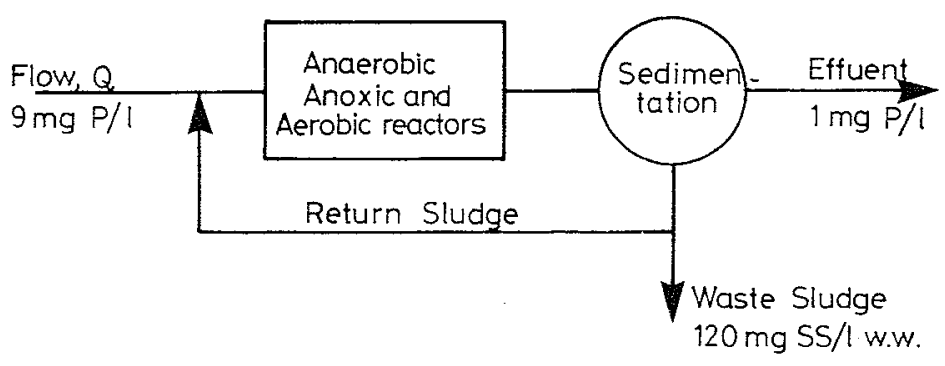

SIDESTREAM PROCESS

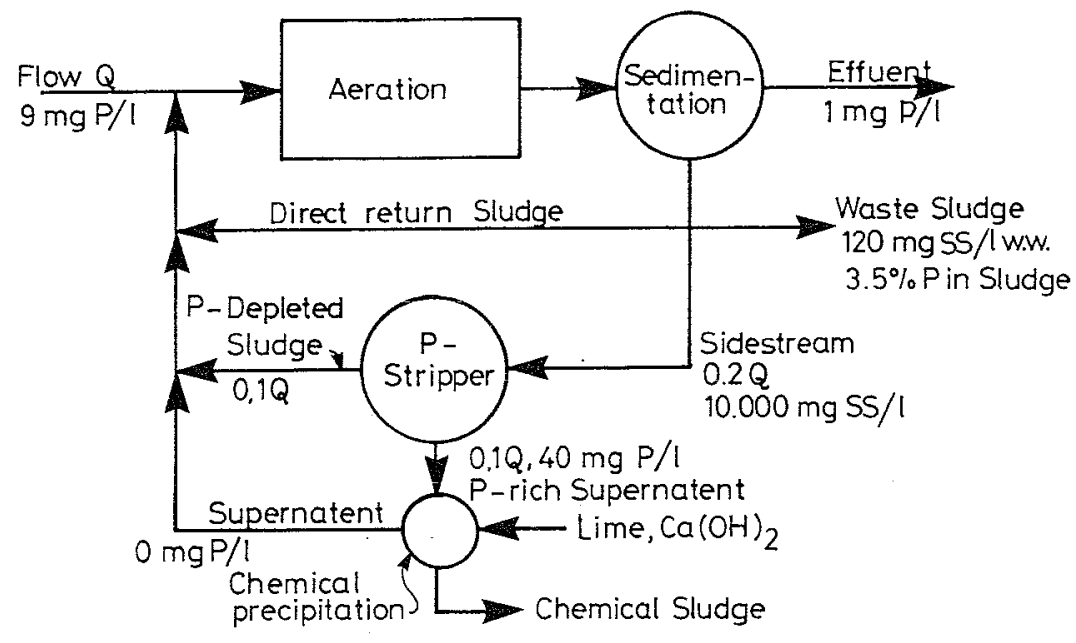

FIGURE.1. Schematic illustration of mainstream and sidestream processes.

For the mainstream process, the requirement is that the surplus sludge contains 6.5 to $7 \% \mathrm{P}$. This is far above the normal sludge $\mathrm{P}$ content of approximately $2 \%$.

In case of the sidestream process, the waste sludge is assumed to contain $3.5 \% \mathrm{P}$ (based on dry weight). ${ }^{2-5}$ Accordingly, $4 \mathrm{mg}$ of $\mathrm{P}$ per liter, or half of the $\mathrm{P}$ removal is withdrawn with the biological waste sludge. The other half is removed by precipitation from the P-rich supernatent leaving the $P$ stripper. If the supernatent is $10 \%$ of the sewage inflow the $P$ concentration is this stream must be approximately $40 \mathrm{mg}$ of $P$ per liter, which is a realistic figure. ${ }^{2,3}$ With a sludge concentration in the return sludge of $10,000 \mathrm{mg}$ of suspended (SS) solids per liter, the decrease in the P content in the P stripper is only $0.4 \%$, from 3.5 to $3.1 \%$.

A characteristic difference between the two processes is that while the mainstream process must contain sludge with high $\mathrm{P}$-accumulation activity, the requirement for the sidestream process is rather that the sludge must be able to exchange a certain amount of $\mathrm{P}$ which in fact is very limited. This may indicate significant differences in P-removal mechanisms between mainstream and sidestream processes. As discussed in Section III, there are, however, common biological features with respect to P-accumulating organisms.

One basic feature in both mainstream and sidestream processes is that the sludge passes through an anaerobic fermentation unit in a cyclic mode. The significance of this is also discussed in Section III.

In practice the sludge from mainstream processes may contain considerably less $P$ than 6.5 to $7 \% \mathrm{P}$. One explanation is that chemical precipitation of $\mathrm{P}$ may occur in the 


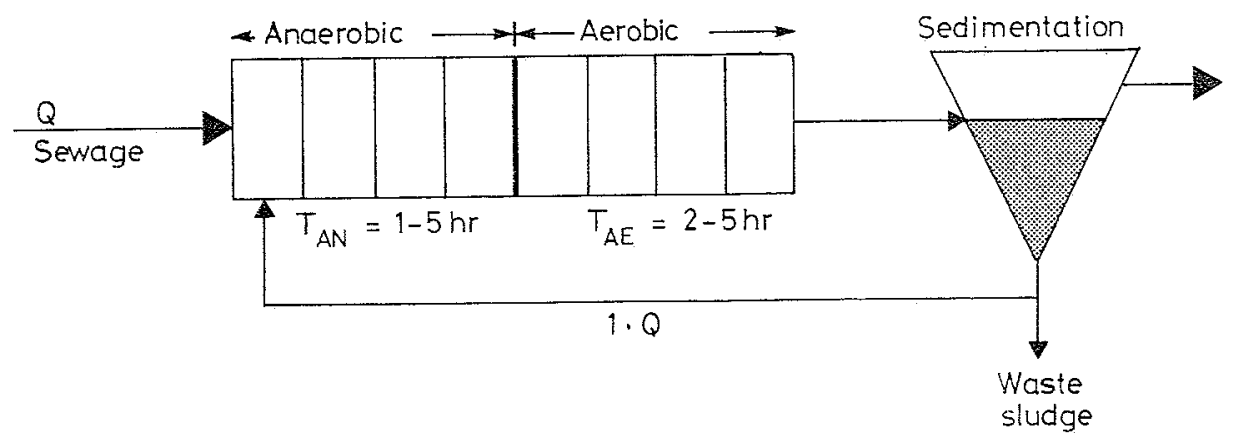

FIGURE 2. Schematic diagram of a mainstream process without nitrogen removal (A) O-process)..$^{6 \cdot 9}$

plant with the natural content of calcium, magnesium, iron, and aluminum in the sewage. The chemical sludge production "dilutes" the P in the sludge. The phosphate precipitation aspects are described in Section IV.

\section{B. Mainstream Processes}

Figures 2 and 3 show various types of mainstream processes schematically, with and without biological nitrogen removal. The processes with nitrogen removal can be divided into recycle processes and alternating processes.

The key process in all systems is the anaerobic fermentation unit with a nominal detention time of about 1 to $2 \mathrm{hr}$. The reactor may be subdivided into several smaller complete mixed tanks.

To achieve efficient denitrification in the recycle systems, a relatively high recycle ratio, normally $4: 1$, is needed. The Badenpho system includes a second anoxic reactor to remove nitrate from the first aerobic reactor.

In the Biodenipho system, nitrogen is removed by alternating two reactors between aerobic and anoxic states. The wastewater from the anaerobic reactor is always fed to the anoxic reactor to provide organic matter for the nitrate reduction. In each phase the wastewater flows through the anaerobic, anoxic, and aerobic reactors. The shift between the aerobic and anoxic state, the phase length, is about $2 \mathrm{hr}$. The alternating system without an anaerobic reactor is called the Biodenitro system. Biological P removal is also observed in this system. ${ }^{16}$

$P$ is generally removed by the surplus sludge. This is taken from the aerobic reactor where the $P$ content in the sludge is maximum. Sludge concentration is best done by flotation to avoid $P$ release from the sludge.

\section{Sidestream Processes}

For the present, two types of sidestream processes have been reported (Figure 4). One is based on a conventional activated sludge plant; the other on the contact stabilization process. The first one, called the Phostrip process, is by far the best documented process and has been implemented in several full-scale plants. The contact stabilization version has only been tested in bench-scale for a limited period.

The key process is the anaerobic phosphate stripper in which part or all of the return activated sludge is treated. This acts like a gravity sludge thickener. During the sludge retention, typically 5 to $20 \mathrm{hr}$, phosphate is released from the sludge to the bulk solution. This P-rich stripper supernatant is treated with lime prior to being returned to the mainstream. The P-depleted underflow sludge is returned to the aeration basin(s) where $P$ uptake from the influent occurs.

Two different principles are currently applied to transfer phosphate released in the sludge blanket in the $\mathrm{P}$ stripper to the supernatant. ${ }^{5}$

Recycle - Underflow from the $P$ stripper is recycled to the stripper feed stream. 


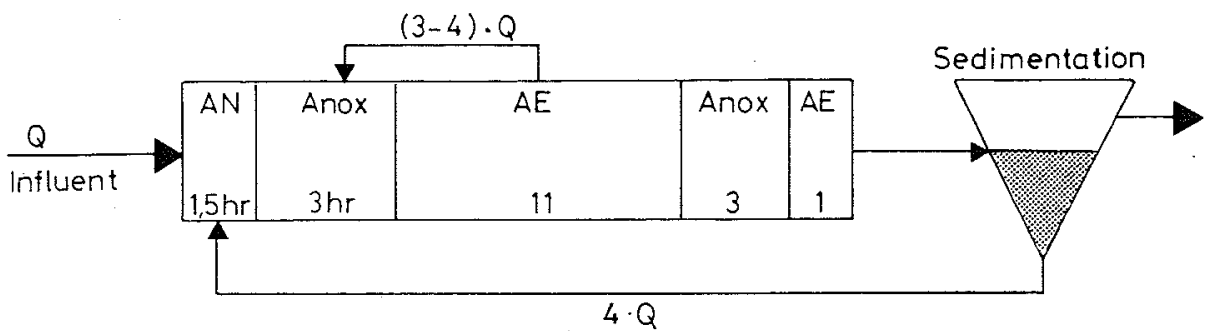

a. BADENPHO (MODIFIED)-PROCESS/PHOREDOX_PROCESS

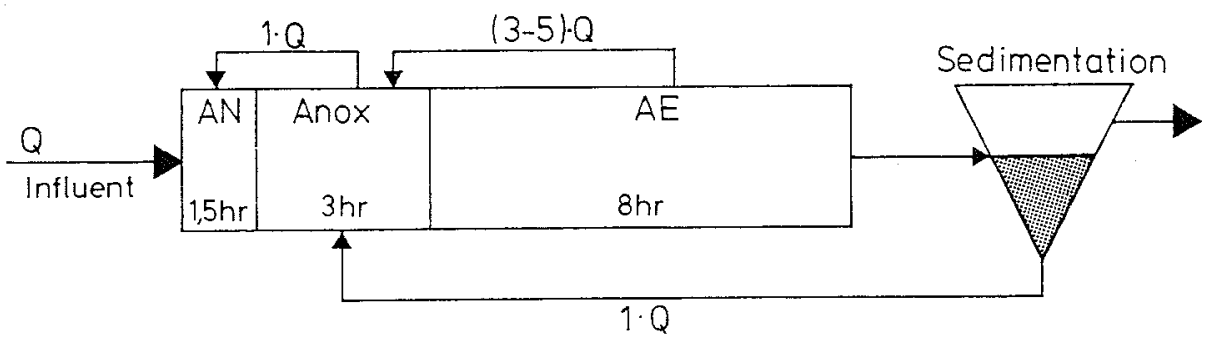

b. UCT-PROCES

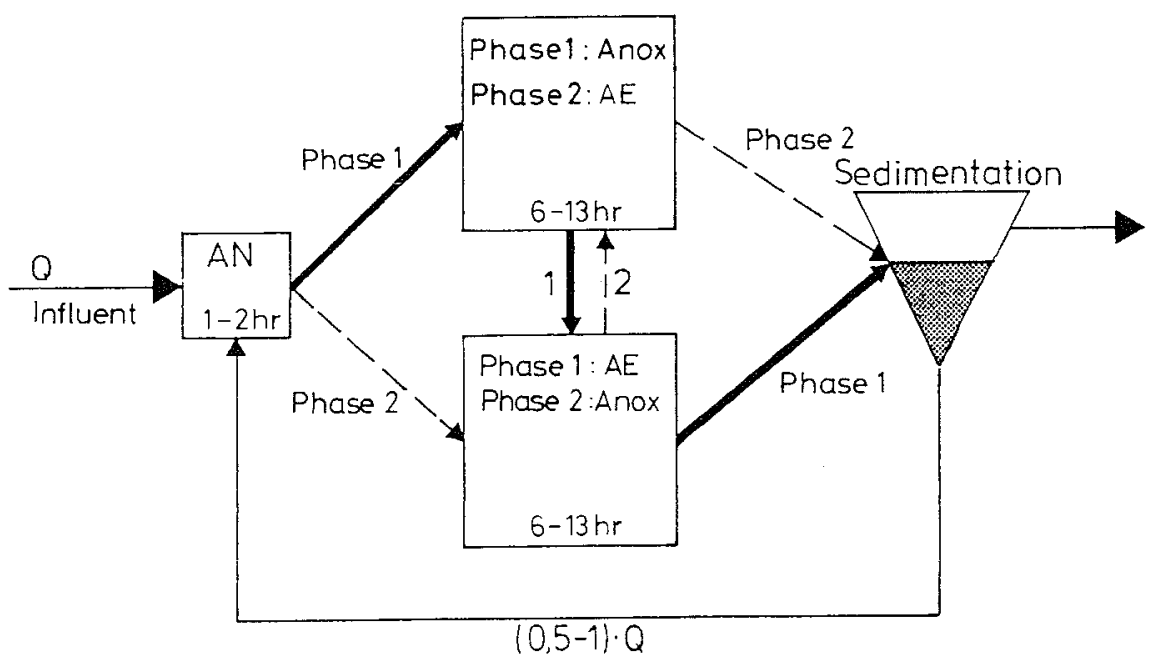

\section{c. BIODENIPHO}

FIGURE 3. Schematic diagram of some mainstream processes with nitrogen removal. Approximate nominal detention times in reactors are indicated: Badenpho (modified) process/phoredox process. ${ }^{10.11}$ UCT process; $;^{12-14}$ Biodenipho process. ${ }^{15.41}$

Elutriation - In this case, a wastewater stream elutriates the sludge in counterstream from the bottom of the P stripper. The wastewater may be raw sewage, primary, secondary, or lime clarifyer effluent. With raw sewage as the elutriant, the difference between the sidestream and the mainstream processes appears to be reduced.

Practical experience has shown that the Photostrip process can produce secondary effluents with total $P$ concentrations of about $1 \mathrm{mg}$ of $P$ per liter. The reason why phosphate precipitation with lime in a sidestream requires much less chemicals compared to mainstream precipitation is that the lime dosage mainly depends on the alkalinity, rather than the $P$ concentration. As the sidestream and mainstream alkalinities are not much different and the sidestream to be treated is only about $10 \%$ of the mainstream, a small amount of lime is needed. 

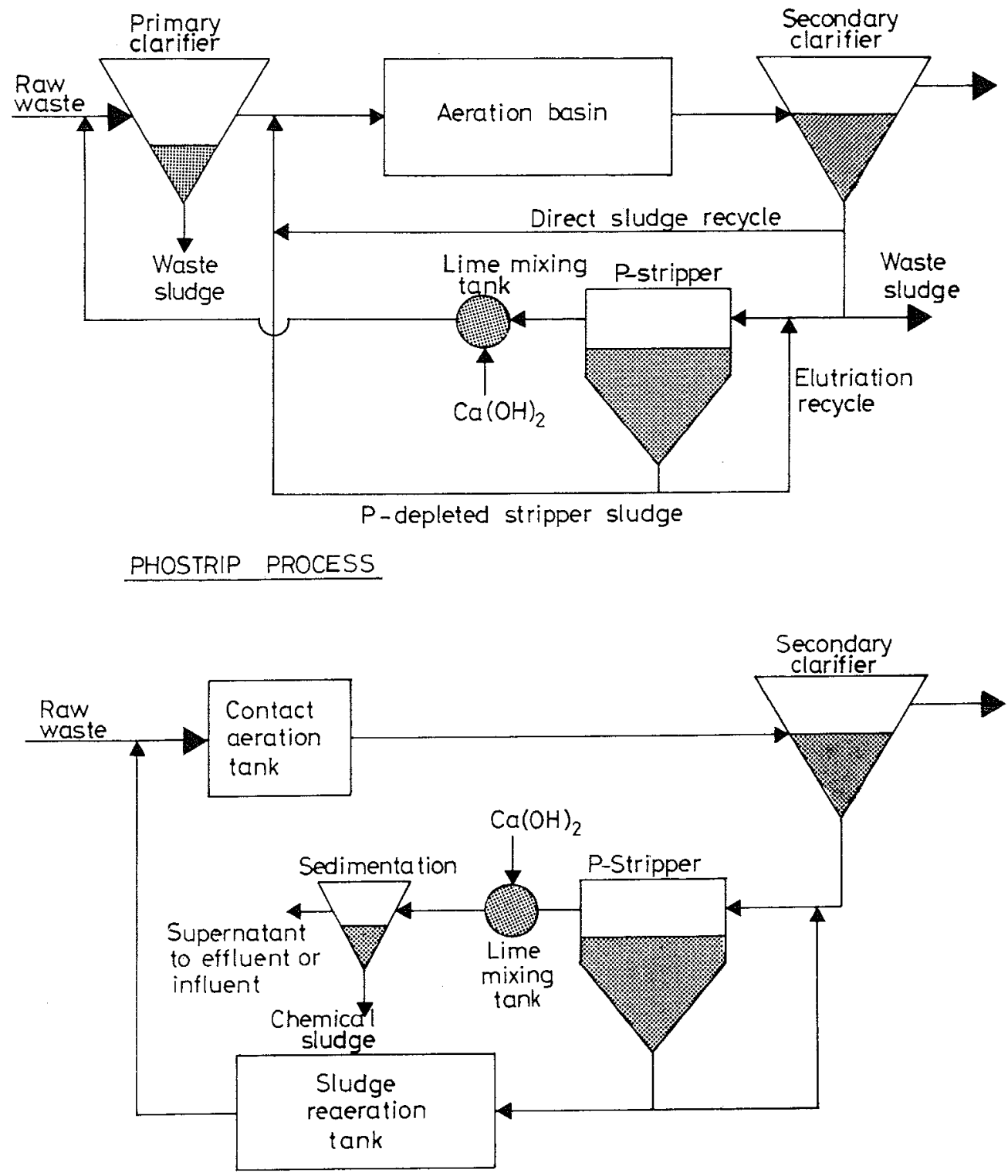

CONTACT STABILIZATION WITH SIDESTREAM P-REMOVAL

FIGURE 4. Schematic diagram of sidestream processes.

In summary, sidestream processes combine biological phosphate extraction from the mainstream and chemical fixation of extracted P. It is in fact a combined biologicalchemical $\mathbf{P}$ removal process.

\section{BIOLOGICAL PHOSPHORUS REMOVAL MECHANISM}

Previous design and operation of treatment plants with biological removal of $P$ has mainly been based on empiricism. This may sometimes lead to sufficient treatment efficiency. However, for example, South African experience with the Badenpho process and similar recycle nitrification-denitrification processes in the period 1976 to 1980 have shown unsatisfactory effluent $P$ concentrations. ${ }^{18}$ This has been attributed to excessive amounts of nitrate and oxygen to the anaerobic basins, mechanical problems, inadequate operator training, insufficient analytical monitoring, etc. This study and others indicate that in addition to better operation management, an improved insight in process mechanisms is needed to obtain better treatment results. 
This chapter will indicate a likely mechanism for enhanced biological $\mathrm{P}$ removal and review factors affecting the net $\mathrm{P}$ removal. The lack of knowledge in many respects will also be pointed out. As a background, the normal biological $\mathrm{P}$ assimilation in biological treatment plants and observations regarding unusual high $\mathrm{P}$ accumulation will be described first.

\section{A. Normal Biological P Assimilation}

Morgan and Fruh ${ }^{19}$ have found for an aerobic system, where phosphate precipitation can be excluded, the sludge $\mathrm{P}$ content is a function of the ratio of $\mathrm{P}$ and organic matter in the raw wastewater. The $P$ content increased from 0.7 to 1.7 to $2.5 \%$ based on volatile suspended solids (VSS) when the COD/P ratio decreased from 2000:1 to less than 60:1.

The maximum $\mathrm{P}$ content of 1.7 to $2.5 \% \mathrm{P}$ is relevant in practice because the COD:P ratio in sewage is roughly $50: 1(20: 1$ to $100: 1)$. It was also found that with a sludge $P$ content higher than $1 \%, \mathrm{P}$ is not growth limiting. Consequently, already the normal $\mathrm{P}$ content of approximately $2 \%$ can be regarded as "luxury uptake".

Stall and Sherrard ${ }^{20}$ found for an aerobic activated sludge system, where phosphate precipitation was also excluded, a sludge P content between 2.2 and $3.6 \%$ based on total suspended solids (SS), corresponding to approximately 2.6 to $4.2 \% \mathrm{P}$ based on VSS ( $85 \%$ VSS). This is considerably higher than what was found by Morgan and Fruh. ${ }^{19}$

These figures indicate that the normal biomass $P$ content for aerobic systems may vary within wide limits. It should be noted that the biomass in the studies mentioned above was grown on soluble substrates. Sewage always contains suspended inorganic and organic matter with relatively low $P$ content. This material is enmeshed in the sludge and will tend to reduce the sludge $P$ content.

Sutton and $\mathrm{Jank}^{21}$ performed experiments with both an aerobic system and combined anoxic/anaerobic/aerobic systems to promote enhanced biological $\mathrm{P}$ removal. The systems were fed with raw, degritted municipal sewage. A wide range of temperatures and solids retention times were applied, 7 to $25^{\circ} \mathrm{C}$ and 3 to 24 days, respectively. The authors found no significant difference in sludge $\mathrm{P}$ content between the systems; any difference in $P$ removal could be attributed to different COD removals. The ratio of $\mathrm{P}$ removal to COD removal, $\triangle \mathrm{P} / \triangle \mathrm{COD}$, was in the range 0.021 to 0.027 . A plot of sludge $P$ contents (based on VSS) in the aeration tank is shown in Figure 5. The sludge $\mathrm{P}$ contents are in the range from 1 to $4 \% \mathrm{P}$, obviously with no dependency of the solids retention time.

$P$ is located in several types of compounds in bacterial cells: nucleic acids (RNA, DNA), nucleotides, phospholipids, sugar phosphates, orthophosphate, and polyphosphates. The inorganic phosphates and the nucleic acids, in particular RNA, are the dominant fractions. In polyphosphate (poly-P)-accumulating organisms, this compound is the main $\mathrm{P}$ fraction. Table 1 shows an example of the $\mathrm{P}$ fractions in Baltimore activated sludge.

The relative cellular content of RNA and poly-P can vary significantly depending on the growth conditions. In rapidly growing cells, the RNA content is relatively high and the poly-P content is low (opposite at low growth rates). There seems to be a reciprocal relationship between the two compounds. ${ }^{23.24}$

\section{B. Enhanced Phosphorus Storage in Cells}

Under conditions of nutrient imbalance unusually high amounts of poly-P accumulate. Harold ${ }^{23}$ found two distinct patterns for this with respect to Aerobacter aerogenes: 


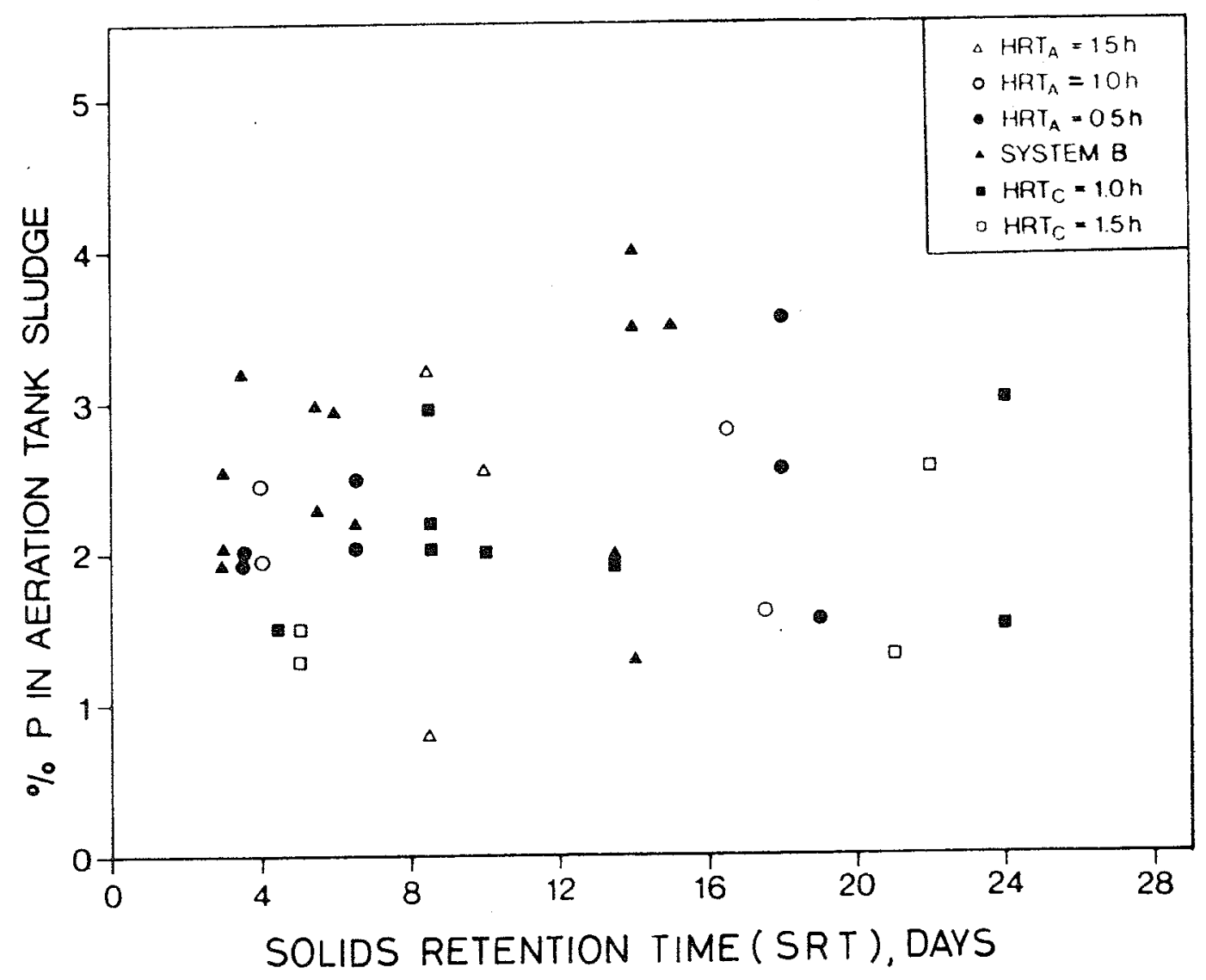

FIGURE 5. P content in sludge vs. solids retention time (SRT). Sludge samples from (1) combined anoxic/anaerobic/aerobic systems designed to achieve nitrification, partial denitrification, and enhanced biological P removal $(\triangle, O, \square, \square)$; and (2) an aerobic system for nitrification only ( $\wedge$ ). Hydraulic retention times, HRT, are the nominal values for the anoxic/anaerobic reactors. (From Sutton, P. M. and Jank, B. E., J. Water Pollut. Control Fed., 52(1), 98, 1980. With permission.)

1. One pattern involved the $\mathbf{P}$ accumulation in conjunction with the cessation of nucleic acid synthesis owing to exhaustion of an essential metabolite, e.g., starvation with respect to sulfur and nitrogen or inhibition due to low pH (luxury uptake).

2. Poly-P accumulates transiently by addition of phosphate to cells previously subjected to phosphate starvation (over-plus mechanisms).

In any case, the accumulation was reversed when growth was allowed to resume. Poly-P was rapidly degraded and the phosphate was quantitatively transferred to the nucleic acid fraction. Potassium, magnesium, and a source of energy are required for poly-P accumulation.

It is not likely that any of these two starvation mechanisms can explain enhanced $P$ storage in cells in biological systems treating municipal sewage. Sulfur, nitrogen, $P$, and zinc seldom reach such low concentrations that starvation is of relevance, nor is inhibition from low $\mathrm{pH}$ values a problem in most practical cases.

Marais et al. ${ }^{12}$ have proposed a mechanism that explains the selection of poly-P accumulating organisms. Poly-P accumulation serves as an energy reservoir to sustain the organism during the anerobic stressed state, but principally to gain a positive advantage over non-P-accumulating organisms by partitioning of readily biodegradable COD (in the lower fatty acid form) in the anaerobic state for its exclusive use subsequently in the aerobic state. Accordingly, the non-poly-P accumulating bacteria get nothing or very little of the readily biodegradable COD. 
Table 1

PHOSPHORUS COMPOUNDS ( $\mu \mathrm{g}$ P/mg dry wt) IN BALTIMORE
ACTIVATED SLUDGE DURING AERATION IN AN ACETATE
MEDIUM

\begin{tabular}{|c|c|c|c|c|c|c|}
\hline \multirow[b]{3}{*}{ Phosphorus compound } & \multicolumn{6}{|c|}{ Treatment and time } \\
\hline & \multicolumn{3}{|c|}{ No treatment (hr) } & \multicolumn{3}{|c|}{$0.05 \mathrm{MEDTA}^{a}(\mathrm{hr})$} \\
\hline & 0 & 2.5 & 5 & 0 & 2.5 & 5 \\
\hline Ortho-P & 4.6 & 6.3 & 8.1 & 0 & 1.8 & 3.8 \\
\hline Nucleotide $\mathbf{P}$ & 4.4 & 4.9 & 5.2 & 4.1 & 4.1 & 3.8 \\
\hline Acid-soluble polyphosphates & 10.2 & 12.2 & 10.1 & 6.4 & 10.2 & 8.7 \\
\hline Lipoid $\mathrm{P}$ & 1.6 & 2.8 & 1.8 & 1.4 & 2.4 & 1.9 \\
\hline Acid-insoluble polyphosphates & 4.0 & 7.0 & 5.5 & 3.7 & 6.9 & 6.0 \\
\hline Nucleic acid and protein $\mathrm{P}$ & 7.0 & 7.6 & 8.7 & 6.8 & 9.1 & 8.4 \\
\hline Sum & 31.8 & 40.8 & 39.4 & 22.4 & 36.5 & 33.7 \\
\hline Total $P$ in supernatant $(\mathrm{mg} / \ell)$ & 32.0 & 2.0 & 0.7 & - & - & - \\
\hline
\end{tabular}

Note: Start concentration of $\mathbf{P}$ in medium: $32 \mathrm{mg}$ of $\mathrm{P}$ per liter. Suspended solids concentration was 2740 to $2800 \mathrm{mg} / \mathrm{\ell}$.

a The sludge was treated with $0.05 M$ EDTA to release externally bound phosphate. In this treatment the $\mathrm{pH}$ decreased from 7 to 5.2.

From Fuhs, F. W. and Chen, M., Microb. Ecol., 2, 130, 1975. With permission.

This is presently a postulate. However, no other mechanism is known that explains the behavior of enhanced biological $P$ removal plants so well.

It was originally proposed by Nicholls and Osborn ${ }^{25,26}$ that poly-P served as an energy reservoir to sustain the organisms during the anaerobic stressed state and to build a reservoir of $\beta$-polyhydroxybutyrate (PHB). Marais et al. ${ }^{12}$ clarified more clearly the role of the readily biodegradable organic matter, which is composed of low molecular soluble organic substances. The aspects of substrate uptake and formation of carbon storage products from the low molecular organics is discussed further in Section III.D.

To illustrate the point, profiles of COD and phosphate in the bulk liquid of a tankin-series system are shown in Figure 6. Most of the organic matter in the settled sewage is removed from the bulk liquid already in the first anaerobic tank. Phosphate is released from the cells with some delay, compared to the COD uptake in the anaerobic tank, and subsequently taken up in the aerobic tank. Figure 7 shows schematically the substrate and phosphate exchange reactions for a poly-P organism.

Future research must show if the Marais hypothesis is correct. An alternative mechanism is proposed by Fuhs and $\mathrm{Chen}^{22}$ and Buchan. ${ }^{27}$ They assume that the function of the anaerobic fermentation reactor is to produce compounds such as ethanol, acetate, and succinate, which serve to enrich Acinetobacter in the subsequent aerobic zone. It is, however, an experimental fact (refer to Figure 6) that the poly-P organisms hoard (sequester) the substrate already in the anaerobic zone if the anaerobic detention time is sufficient and very little of the organics enter the aerobic (and the anoxic) reactor.

Virtually nothing is presently known regarding the growth competition between poly-P organisms and nonpoly-P organisms in the aerobic reactor. The establishment of such growth-kinetic data is an important future research task. It is neither known if the poly-P organisms are able to grow in anoxic reactors, i.e., to use nitrate as an 


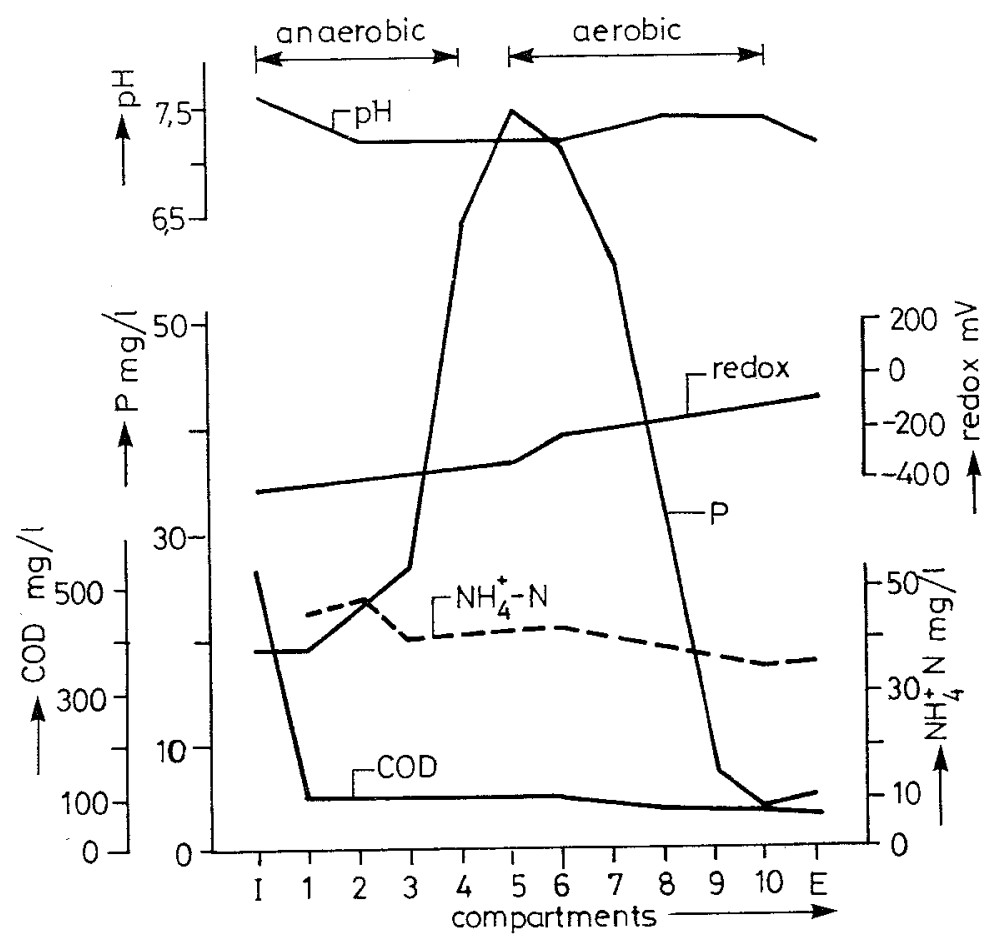

FIGURE 6. Profiles of $\mathrm{COD}, \mathrm{PO}_{4}-\mathrm{P}, \mathrm{NH}_{4}-\mathrm{N}, \mathrm{pH}$, and redox in a ten-compartment system (refer to Figure 2). First five tanks are anaerobic; last five tanks are aerobic. I, influent; $\mathrm{E}$, effluent; sludge loading, $0.6 \mathrm{~kg} \mathrm{COD} / \mathrm{kg} \mathrm{MLSS} /$ day; temperature, $18^{\circ} \mathrm{C}$, MLSS, $3.4 \mathrm{~g} / \ell$. (From Rensink, J. H., Donker, H. J. G. W., and de Vries, H. P., 5th European Sewage and Refuse Symp. EAS, Munich, Gesellschaft zur Förderung der Abwassertechnik, e. v., St. Augustine, 1981, 487.

ANAEROBIC REACTOR

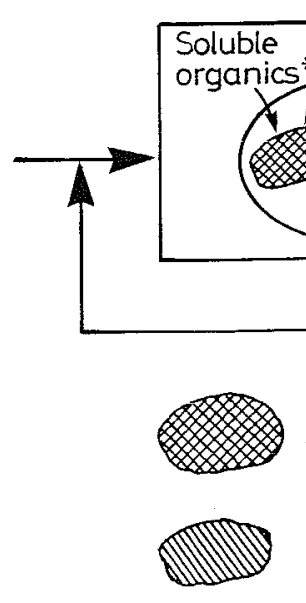

DN: Possible denitrification reactor
Accumulated carbonacious materiel

Polyphosphate voluntin granules

\section{DN AEROBIC REACTOR}
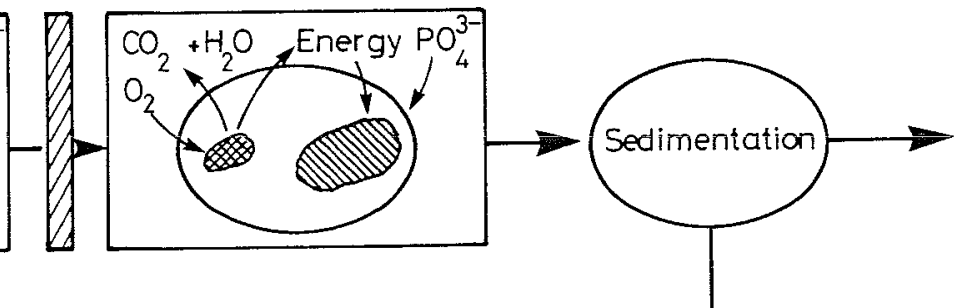

* Readily biodegradable organics (Low molecular soluble organics, for example acetic acid).

FIGURE 7. Schematic illustration of exchange of soluble organics and phosphate in a biological P-removal plant.

electron acceptor. Acinetobacter should not be able to use nitrate as an electron acceptor. ${ }^{28}$ Whether other poly-P accumulating organisms use nitrate as an electron acceptor and, by this, compete with the nonpoly-P organisms in the anoxic reactor reactor is not yet clear. 
In the discussion on mechanisms above, no distinction has been made between mainstream processes and sidestream processes. It is not known yet if there are significant differences in mechanism. However, there are reasons to believe that poly-P organisms also play an important role in sidestream processes and that these organisms get an advantage over nonpoly-P organisms because they are able to sequester low molecular organics in the anaerobic reactor ( $\mathrm{P}$ stripper). Unlike the mainstream processes, the low molecular organics in the sidestream anaerobic reactor are formed by hydrolyzation of particulate organics and from lysed bacteria during the relatively. long detention time, about $10 \mathrm{hr}$. If this is correct, the increase in phosphate concentration in the $\mathrm{P}$ stripper comes from poly-P bacteria and from lysed bacteria. In mainstream processes, where the anaerobic detention time is only 1 to $2 \mathrm{hr}$, the increase in phosphate concentration in the anaerobic reactor probably comes by far from poly-P bacteria.

\section{Polyphosphate Accumulation}

A wide range of organisms are able to accumulate poly-P. ${ }^{23,24}$ Acinetobacter spp. are most often reported as the dominating organism in P-removal plants. ${ }^{9,22,25,27,29}$ Acinetobacter also has the ability to accumulate lipids as a carbon reserve material, e.g., $\beta$ polyhydroxybuturate (PHB) and $\beta$-polyhydroxylauric acid. In addition, the bacteria can produce extracellular polysaccharide capsules. ${ }^{28,29}$

In some biological P-removal plants, other bacteria than Acinetobacter have dominated: Aeromonas, Pseudomonas, and Pasteurella. ${ }^{30}$ Malnon et al. ${ }^{31}$ found that apart from Acinetobacter, the organisms Pseudomonas and Aeromonas were also abundant. The authors noted that Acinetobacter produces agglomerates, caused by an extracellular capsular material, which probably tend to underestimate these bacteria.

In order to estimate how much $\mathrm{P}$ can be removed in biological treatment plants, it is of interest to know how much $P$ can be accumulated in bacteria. Malnon et al. ${ }^{31}$ found a $\mathrm{P}$ content of 10 to $12 \% \mathrm{P}$ in a pure culture of Acinetobacter grown on acetate medium. They also found that in a medium not containing acetate, the Acinetobacter only contained 1.5 to $2.5 \% \mathrm{P}$. This means that the high $\mathrm{P}$ accumulation appears to be strictly related to the presence of volatile fatty acids, such as acetic acid.

Fukase et al. ${ }^{32}$ observed a maximum $\mathrm{P}$ content of $12.8 \%$ in an activated sludge culture grown on acetate with a 5.8-day solid retention time. As part of the sludge consists of dead bacteria (endogenous biomass), the $\mathrm{P}$ content in the viable biomass must be even higher than $12.8 \%$.

In their studies with an Acinetobacter culture, Deinama et al. ${ }^{29}$ found at maximum $10 \% \mathrm{P}$. The culture was grown in a butyrate and lactate medium. Surprisingly, Fuhs and Chen, ${ }^{22}$ who also worked with an Acinetobacter strain (A. Iwoffi), obviously did not observe cell $P$ contents above $5 \%$, even though the culture was grown on acetate medium. Some researchers have worked with other P-accumulating bacteria than Acinetobacter. Shoda et al. ${ }^{33}$ and Tamatami et al. ${ }^{34}$ found up to $7 \% \mathrm{P}$ in cells of Arthrobacter globiformis grown on a glucose medium. Most of the cell $\mathrm{P}$ was bound in nucleic acids (RNA).

Considering activated sludge systems where the substrate is not an artificial medium consisting of acetate, etc., but ordinary sewage, the highest sludge P contents are 6 to $7 \%$ P. Examples of this are in the Rilling plant, San Antonio, ${ }^{35,36}$ where the sludge $P$ content was 6 to $8 \% \mathrm{P}$; in the Baltimore plant, up to $5 \% \mathrm{P}$ was observed. ${ }^{37}$ Rensink et al. ${ }^{9}$ found a maximum of $6.8 \% \mathrm{P}$ and Deakyne ${ }^{7}$ observed 4.5 to $6 \% \mathrm{P}$. As noted previously, only part of the biomass in these activated sludge systems are viable cells and therefore the $\mathrm{P}$ content in active cells is probably significantly higher than 6 to $7 \%$.

To answer the question of how much $P$ can be accumulated in bacteria, one may use the $\mathrm{P}$ content in pure poly- $\mathrm{P}$ as a basis. Depending on the counterion, the $\mathrm{P}$ content 
varies: $\left(\mathrm{KPO}_{3}\right)_{n}$ contains $26 \% \mathrm{P},\left(\mathrm{Mg}\left(\mathrm{PO}_{3}\right)_{2}\right)_{n}$ contains $34 \% \mathrm{P}$, and $\left(\mathrm{Ca}\left(\mathrm{PO}_{3}\right)_{2}\right)_{n}$ contains $31 \% \mathrm{P}$. All three cations appear to function as counterions, obviously with potassium and magnesium as the dominating cations, judged from biological P-release experiments. ${ }^{5}$ From the figures above, a maximum of about $30 \% \mathrm{P}$ in poly-P can be expected. Considering that volutin granules also contain proteins and lipids, ${ }^{23.24,38}$ the actual $\mathrm{P}$ content in the granules is expected to be lower than $30 \%$. Buchan ${ }^{27}$ actually found between 18 and $25 \% \mathrm{P}$. If the poly-P granules constitute as much as two thirds of the cell weight and the $\mathrm{P}$ content in the granules is $25 \% \mathrm{P}$, the cell $\mathrm{P}$ content from poly- $\mathrm{P}$ is about $17 \% \mathrm{P}$. As some $\mathrm{P}$ is also present in nucleic acids, lipids, etc., one may guess that the maximum cell $\mathrm{P}$ content is about $20 \% \mathrm{P}$. Siebritz et al. ${ }^{13}$ assume in their modeling of biological excess $P$ removal that the active biomass can contain up to $35 \%$ $P$. This appears unrealistic based on the previous discussion.

\section{Polyphosphate as an Energy Reserve}

The possible role of poly-P as an energy reserve (Phosphagen) in bacteria has been a key point for many years in the discussions of the feasibility of enhanced biological $P$ removal. In his review on polyphosphates from 1966, Harold ${ }^{23}$ doubted that energy storage is the principal function of poly-P. As a result of this statement, researchers have obviously been reluctant to accept the role of poly-P organisms and have had difficulties seeing selection mechanisms for such organisms.

Today, however, there is clear evidence that poly-P can act as an energy reserve, either through phosphorylation of AMP and ADP to ATP or through direct phosphorylation of of substrates like glucose, fructose, mannose, gluconate, acetate, glycerol, serine, etc. ${ }^{24,39.40}$ Reference is made to $\mathrm{Kualev}^{24}$ for his comprehensive monograph on the biochemistry of polyphosphates.

\section{E. Organic Substrate Uptake and P Release}

In biological P-removal plants, the poly-P organisms have the function of both accumulating poly-P, and also removing organic matter from the sewage. Recent research deals with the extent of substrate uptake by the poly-P organisms in the anaerobic fermentation reactor. Fukase et al..$^{32}$ found a correlation between the amounts of glucose and acetate removed and the release of phosphate, the mole ratios being: glucose $/ \mathrm{PO}_{4}=2.1$ and acetate $/ \mathrm{PO}_{4}=1.1$. Arvin et al. ${ }^{41}$ observed molar exchange ratios of glucose $/ \mathrm{PO}_{4}=0.6$ to 0.8 and acetate $/ \mathrm{PO}_{4}=0.7$. Siebritz et al. ${ }^{42}$ expressed the $\mathrm{P}$ release in terms of acetate added and found that $2 \mathrm{~mol}$ of acetate added released $1 \mathrm{~mol}$ $\mathrm{PO}_{4}-\mathrm{P}$. Although it is likely, it is not clear from the data if all the acetate added is actually removed.

Marais et al..$^{12}$ propose some biochemical reactions to explain the uptake of acetate and glucose and release of phosphate. Assuming the storage of acetoacetate from acetate, the net reaction is

$$
2 \text { acetate }+\left(\mathrm{P}_{\mathrm{i}}\right)_{\mathrm{n}} \rightarrow \text { acetoacetate }+\left(\mathrm{P}_{\mathrm{i}}\right)_{\mathrm{n}-2}+2 \mathrm{P}_{\mathrm{i}}
$$

where $\left(\mathrm{P}_{i}\right)_{n}$ denotes the poly- $\mathrm{P}$ chain and $\mathrm{P}_{i}$ denotes phosphate released. This reaction gives an acetate $/ \mathrm{PO}_{4}$ molar exchange ratio of 1 .

For glucose Marais et al. ${ }^{12}$ differentiate between the two situations where poly-P organisms cannot utilize glucose, and the second where they can accept glucose as a carbon source. In the first situation, the facultative nonpoly-P accumulating organisms convert glucose to acetate, which is subsequently absorbed by the poly-P organisms. The net result is a molar glucose/ $/ \mathrm{PO}_{4}$ exchange ratio of 1 :

$$
1 \text { glucose }+\left(\mathrm{P}_{\mathrm{i}}\right)_{n} \rightarrow 1.5 \text { acetoacetate }+\left(\mathrm{P}_{\mathrm{i}}\right)_{n-1}+\mathrm{P}_{\mathrm{i}}
$$


Table 2

EFFECT OF DIFFERENT
SUBSTRATES ON PHOSPHATE
RELEASE

$\begin{array}{lc}\begin{array}{c}\text { Substrate } \\ \text { COD conc } 110 \mathrm{mg} \ell^{-1}\end{array} & \begin{array}{c}\text { Phosphate release } \\ \left(\mathrm{mg} \ell^{-1}\right)\end{array} \\ \text { Formate } & 28.4 \\ \text { Acetate } & 58.6 \\ \text { Propionate } & 54.5 \\ \text { Butyrate } & 8.2 \\ \text { Hydroxybutyrate } & 5.9 \\ \text { Glucose } & 5.0 \\ \text { Ribose } & 0.0 \\ \text { Glycerol } & 0.0 \\ \text { EDTA } & 0.0\end{array}$

From Potgieter, D. J. J. and Evans, B.W., Water Sci. Technol., 15, 105, 1983. With permission.

This ratio is considerably lower than the ratios found by Fukase et al..$^{32}$ In the second case, Marais et al. ${ }^{12}$ state that the net reaction depends on the relative fractions of nonpoly-P and poly-P organisms.

The effect of different substrates on $\mathrm{P}$ release was investigated by Potgieter and Evans $^{43}$ with sludge from a Phoredox pilot plant. The result is shown in Table 2. It is obvious that acetate and proprionate greatly enhance $P$ release, formate has a significant effect, and butyrate, hydroxybutyrate, and glucose have a relatively small effect.

There is still much to learn about the utilization of organic substrates. The term "readily biodegradable organics" introduced by Marais et al. ${ }^{12}$ is not well defined in relation to phosphate release and growth of poly-P organisms.

\section{F. Effect of Environmental Factors on P Uptake and Release}

Several researchers have demonstrated the importance of biological activity on the aerobic $P$ uptake through inhibition experiments. Levin and Shapiro ${ }^{44}$ showed that $2,4-$ dinitrophenol (2,4-DNP), a decoupler of biological oxidative phosphorylation, inhibited $\mathrm{P}$ uptake. The $\mathrm{P}$ uptake was also inhibited by $\mathrm{Hg}^{2+}$, iodoacetic acid, and azide. ${ }^{45}$ Carberry and Tenney ${ }^{46}$ and Rensink et al. ${ }^{9}$ observed $P$ release as a result of the $2,4-$ DNP addition to an aerobic system.

The optimum pH range for aerobic $\mathrm{P}$ uptake is 7 to 8 according to Levin and Shapiro. ${ }^{44}$ In the experiments by Boughton et al. ${ }^{45}$ the $\mathrm{pH}$ range was 7.5 to 9.6. They also determined an optimum temperature range -24 to $37^{\circ} \mathrm{C}$.

Obviously very little knowledge exists on the effect of $\mathrm{pH}$, temperature, inhibitors, etc. on the anaerobic $\mathrm{P}$ release. Shapiro et al. ${ }^{47}$ investigated the effect of temperature. This was clearly an important factor, as the P-release rate increased with a factor of 2.1 to 2.6 by a $10^{\circ} \mathrm{C}$ increase.

\section{CHEMICAL PHOSPHATE PRECIPITATION IN BIOLOGICAL P- REMOVAL SYSTEMS}

Enhanced $\mathrm{P}$ removal in biological treatment plants may to some extent be due to chemical precipitation of phosphate. Figure 8 illustrates the transformations of $P$ between the bulk liquid and the sludge in a biological treatment plant. 


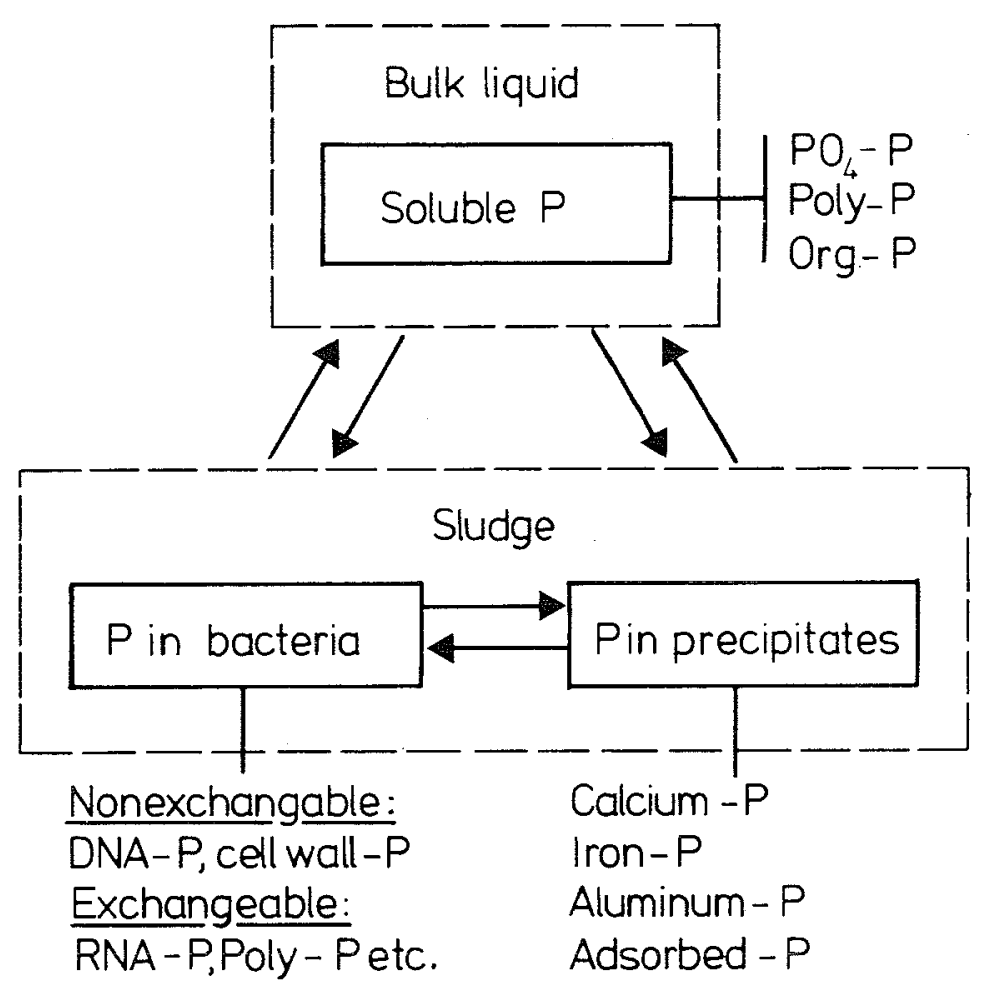

FIGURE 8. Transformation of $\mathrm{P}$ between the bulk liquid and sludge. Main $\mathrm{P}$ fractions are shown. (From Arvin, E., Water Sci. Technol., 15, 43, 1983. With permission.)

The simultaneous precipitation can be a result of cations present in the wastewater. One important cation is calcium. This is present in all wastewater in amounts normally between 30 to $100 \mathrm{mg} / \ell$. Magnesium, iron, aluminum, and zinc also contribute to the fixation of phosphate. The concentration of the cations often lies in the range: $\mathrm{Mg}, 5$ to $30 \mathrm{mg} / \ell ; \mathrm{Fe}, 0.5$ to $3 \mathrm{mg} / \ell ; \mathrm{Al}, 0.1$ to $2 \mathrm{mg} / \ell$; and $\mathrm{Zn}, 0.1$ to $2 \mathrm{mg} / \ell$. If the fraction of industrial wastewater in the sewage is high, the concentrations of $\mathrm{Fe}, \mathrm{Al}$, and $\mathrm{Zn}$ may be even higher.

Small amounts of the soluble phosphate in the sewage may also be transferred to the sludge phase by adsorption to clay particles and other minerals. These minerals are sometimes washed to the sewers in significant amounts, e.g., with urban storm water. However, as the amount of phosphate removed by absorption at best is small, up to $0.1 \mathrm{mg}$ of $\mathbf{P}$ per liter based on adsorption capacity considerations, adsorption will be neglected in the following. It should be mentioned that the soil minerals in the sludge may act as nucleation sites for in arganic phosphates and accordingly they may be important in order to create a high specific surface area for phosphate precipitation.

Table 3 illustrates that a moderate transformation of $\mathrm{Ca}, \mathrm{Mg}, \mathrm{Fe}, \mathrm{Al}$, and $\mathrm{Zn}$ to phosphates can remove $6 \mathrm{mg}$ of $\mathrm{P}$ per liter. The concentration of $\mathrm{P}$ in sewage is normally 5 to $15 \mathrm{mg}$ of $\mathrm{P}$ per liter which means that chemical precipitation as shown in Table 3 may contribute significantly to the total $P$ removal.

Chemical precipitation of $P$ can be divided into bulk precipitation and biofilm precipitation. In bulk precipitation, the growth of the solid phosphate phase is governed by the composition of the bulk liquid, but the material is incorporated in the sludge by flocculation. Biofilm precipitation happens inside biofilms and is controlled by the biofilm microenvironment which may be very different from the bulk liquid, e.g., with respect to $\mathrm{pH}$.

A basic hypothesis in the following is that enhanced $\mathrm{P}$ removal in biological treatment plants may be partly due to $P$ precipitation mediated by the macro- and microen- 


\section{Table 3 \\ POTENTIAL REMOVAL OF PHOSPHATE BY CHEMICAL PRECIPITATION}

$\begin{array}{lcccc}\text { Cation } & \begin{array}{c}\text { Concentration } \\ \text { in sewage } \\ (\mathrm{mg} / \mathrm{l})\end{array} & \begin{array}{c}\text { Removal } \\ (\mathrm{mg} / \mathrm{l})\end{array} & \begin{array}{c}\text { Cation/P } \\ \text { molar } \\ \text { ratio }\end{array} & \begin{array}{c}\text { P removal } \\ (\mathrm{mmol})\end{array} \\ \mathrm{Ca} & 30-100 & 5 & 1.5 & 0.08 \\ \mathrm{Mg} & 5-30 & 2 & 1.5 & 0.05 \\ \mathrm{Fe} & 0.5-3 & 1 & 1 & 0.02 \\ \mathrm{Al} & 0.1-2 & 0.7 & 1 & 0.03 \\ \mathrm{Zn} & 0.1-2 & 0.8 & 1.5 & 0.01 \\ & & & & 0.19 \sim 6 \mathrm{mg} \mathrm{P} / \ell\end{array}$

vironment of the biomass. The following types of biologically mediated P precipitation will be dealt with: (1) accelerated bulk precipitation created by the elevated $P$ concentrations in the anaerobic reactor due to $\mathrm{P}$ stripping from bacteria, e.g., from polyphosphate pools, and (2) biofilm precipitation mediated by the elevated $\mathrm{pH}$ in denitrifying biofilms. The first type of mediation is not linked to nitrifying/denitrifying processes as the second is. In both cases, the biomass acts as a "P pump", pumping $P$ from the soluble phase to the solid phase. The elements of this theory are explained in the following sections.

\section{A. Phosphate Precipitation Mediated by Anaerobic P Release}

The anaerobic reactor may be important to promote chemical precipitation. ${ }^{48}$ The higher the $\mathbf{P}$ concentration obtained in the anaerobic reactor by biological $\mathrm{P}$ release, the faster the precipitation rate in a dynamic P-precipitation state. The growth rate of apatite crystals in pure chemical systems can be described by the following equation: ${ }^{49}$

$$
\frac{\mathrm{dP}}{\mathrm{dt}}=\mathrm{k} \cdot \mathrm{s} \cdot \frac{\left(\mathrm{Ca}^{2+}\right)^{5}(\mathrm{P})^{3}}{\left(\mathrm{H}^{+}\right)^{4}\left(\mathrm{CO}_{3 \mathrm{~T}}\right)}
$$

where $\mathrm{P}$ is $\mathrm{P}$ concentration, $\mathrm{t}$ is time, $\mathrm{CO}_{3 T}$ is total inorganic carbon concentration, $\mathrm{s}$ is specific surface area of crystals, and $\mathrm{k}$ is a constant.

This means that the precipitation rate is third order with respect to the phosphate concentration, which is in agreement with previous results. ${ }^{50}$ Zoltec $^{51}$ found a near second order relationship in the final growth phase.

The precipitation is also promoted by a relatively high $\mathrm{pH}$, calcium concentration, and surface area for crystal growth. The inhibiting effect of carbonate will be further commented on in the following.

Apart from accelerating the $\mathrm{P}$ precipitation, a high $\mathrm{P}$ concentration can induce nucleation of solid $\mathrm{P}$ phases in systems, where the supersaturation otherwise is too small for nucleation to occur.

As pointed out by Kerdachi and Roberts, ${ }^{52,53}$ the anaerobic zone may also have the function of reducing and solubilizing iron from nonphosphate compounds like iron hydroxids, whereby it can combine with calcium and $\mathrm{P}$ to calcium ferrous phosphate.

In order to obtain a net $\mathrm{P}$ precipitation, the $\mathrm{pH}$, the calcium activity, and other precipitation-determining factors in the final aerobic treatment steps must be such that none or only some part of the anaerobically precipitated $P$ redissolve. The P-removal mechanisms outlined above are illustrated in Figure 9. The poly-P containing bacteria are the "P pumps" in the system, pumping $P$ from the bulk liquid of the aerobic tank 


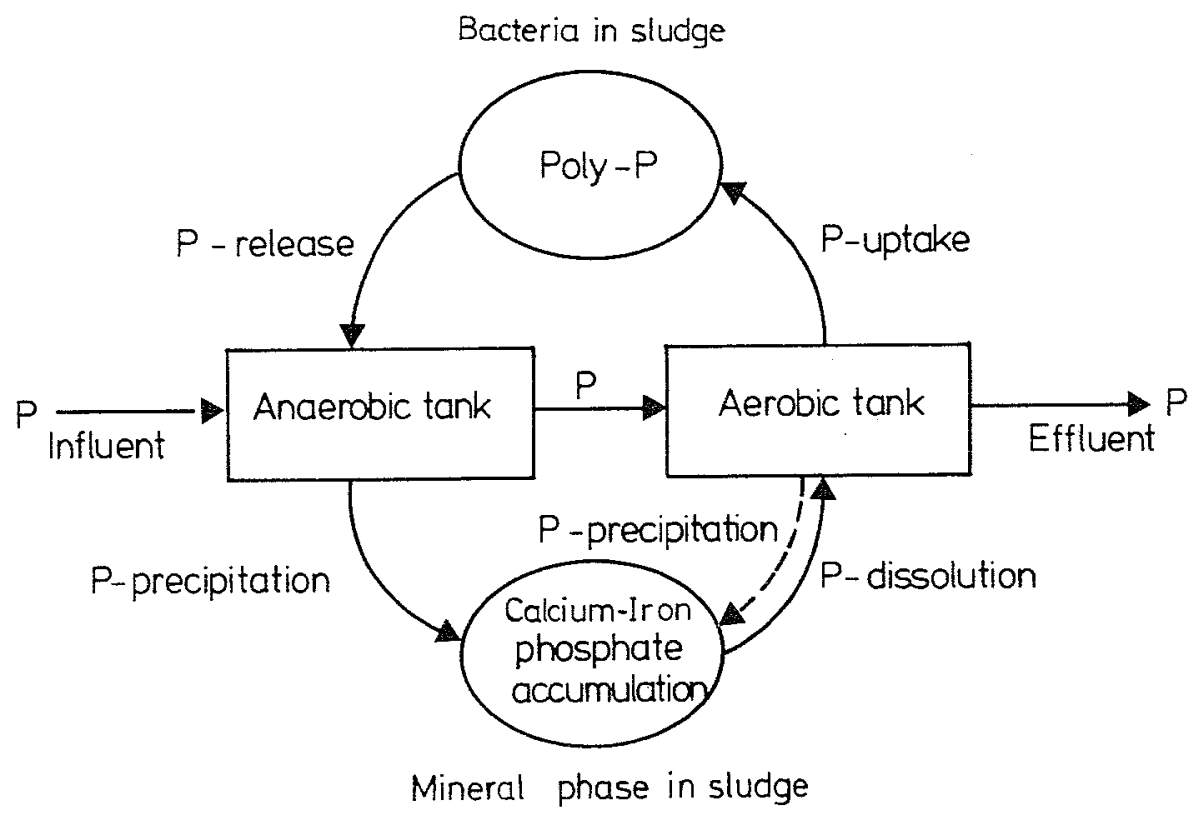

FIGURE 9. Illustration of how phosphate may be accumulated in mineral phase mediated by poly-P-containing bacteria. (From Arvin, E., Water Sci. Technol., 15, 43, 1983. With permission.)

to the anaerobic tank, where part of it precipitates and is accumulated in the mineral phase.

\section{B. Phosphate Precipitation in Biofilms Mediated by Denitrification}

Denitrification with, for example, acetate or methanol is an alkalinity-producing reaction. The resistance to outdiffusion of alkalinity $\left(\mathrm{HCO}_{3}{ }^{2-}\right.$ and $\left.\mathrm{CO}_{3}{ }^{2-}\right)$ in biofilms may lead to a $\mathrm{pH}$ increase inside the biofilm compared to $\mathrm{pH}$ of the bulk liquid.

It has been shown theoretically and experimentally that a relatively high biofilm pH is produced by a high denitrification rate (high nitrate concentration and a deep active biofilm), a low bulk alkalinity, and a high bulk pH. These factors together with a high calcium concentration promote calcium phosphate precipitation in the biofilm. ${ }^{54,55}$

Denitrification does not only happen in anoxic treatment steps. Riemer and Harremoes $^{56}$ have shown that denitrification can also proceed in aerobic treatment steps in the inner parts of biofilms. $P$ precipitation induced by denitrification may therefore also happen under aerobic conditions in the bulk liquid.

\section{Phosphate Precipitation in Biological Systems}

In evaluating the role of phosphate precipitation in biological treatment plants and in planning experimental programs, it is essential to know the type of phosphate phases formed, the influence of various wastewater constituents on this phase formation, and the solubility and precipitation rates. These aspects will be reviewed in the following.

It is normally assumed that if $\mathrm{P}$ precipitation occurs in a biological treatment plant, the solid phase is an amorphous or poorly crystalline calcium phosphate like tricalcium phosphate (TCP) or hydroxyapatite (HAP).$^{50.57 .58}$ Detailed characterization of the phases does not seem to be available. However, this subject has been investigated intensively in relation to tooth enamel and bone formation under experimental conditions relevant to the composition of wastewater.

In biological systems and inorganic model systems, well-defined, simple calcium phosphates never form. Tooth enamel and bone, for example, are not made by pure hydroxyapatite. It has been shown by several investigators that these biological calcium 
phosphates are amorphous or poorly crystalized apatites contain carbonate in particular and small amounts of various cations and anions $\left(\mathrm{Na}^{+}, \mathrm{Mg}^{2+}, \mathrm{Fe}^{3+}, \mathrm{Fe}^{2+}, \mathrm{Al}^{3+}, \mathrm{Zn}^{2+}\right.$, $\mathrm{F}^{-}$, etc. ${ }^{59-68}$ One example given by Bonel et al. ${ }^{63}$ and Montel et al..$^{64}$ is a precipitate with sodium, carbonate, and fluoride substitution:

$$
\begin{aligned}
& \mathrm{Ca}_{10-x} \mathrm{Na}_{2 / 3}\left(\mathrm{PO}_{4}\right)_{6-x}\left(\mathrm{CO}_{3}\right)_{x}\left(\mathrm{H}_{2} \mathrm{O}\right)_{x}(\mathrm{OH}, \mathrm{F})_{2-x / 3} \\
& 0<\mathrm{x}<3
\end{aligned}
$$

According to this formula, the calcium/phosphorus molar ratio may be as high as 2.33, whereas in hydroxyapatite it is 1.67 .

Amorphous calcium phosphate (ACP) is expected to be a precursor for the biological apatities. The composition of ACP can be approximated with the formula $\mathrm{Ca}_{9}\left(\mathrm{PO}_{4}\right)_{3}$ which is similar to the composition of $\beta$-tricalcium phosphate. ${ }^{66,68}$ Another precursor may be octacalcium phosphate (OCP) or even dicalcium phosphate (DCP).

The sequence of calcium phosphate precipitation leading to hydroxyapatite (HAP) formation is expected to be ${ }^{69}$

$$
\mathrm{ACP} \rightarrow \mathrm{OCP} \rightarrow \mathrm{HAP}
$$

The higher the $\mathrm{pH}$ and calcium activity, the higher is the affinity for hydroxyapatite formation.

Certain ions which are always present in wastewater stabilize the ACP phase to such an extent that OCP or the substituted apatites may never form in practice. According to Legeros. ${ }^{60,62}$ the efficiency of the following ions to decrease the crystallinity of apatite and promoting the formation of $\mathrm{ACP}$ is

$$
\left(\mathrm{Mg}^{2+}+\mathrm{P}_{2} \mathrm{O}_{7}{ }^{4-}\right)>>\left(\mathrm{P}_{2} \mathrm{O}_{7}^{4-}\right)>>\left(\mathrm{Mg}^{2+}+\mathrm{HCO}_{3}^{-}\right)>>\mathrm{Mg}^{2+}>>\mathrm{HCO}_{3}^{-}
$$

Pyrophosphates are particularly strong inhibitors of both crystal growth and dissolution. The same applies to phosphonates, e.g., diphosphonates. Such compounds may be in the wastewater because they are used to prevent scaling in cooling systems. Polyvalent carboxylic acids like citric acid are also known to suppress crystal growth of apatites.

The effect of $\mathrm{Mg}^{2+}$ to stabilize ACP and to inhibit the nucleation and crystallization of apatites is significant at a $\mathrm{Mg} / \mathrm{Ca}$ molar ratio greater than 0.45 . Magnesium also enhances the effects of pyrophosphate (PP) and carbonate. Legeros ${ }^{60}$ indicates that while it takes a $\mathrm{HCO}_{3} / \mathrm{PO}_{4}$ molar ratio of 20 or above or a $\mathrm{Mg} / \mathrm{Ca}$ molar ratio of at least 0.45 to produce $\mathrm{ACP}$, it only needs a $\mathrm{HCO}_{3} / \mathrm{PO}_{4}$ ratio of 5 when $\mathrm{Mg}$ is present $(\mathrm{Mg} / \mathrm{Ca}=0.1)$. Similarly, in the absence of $\mathrm{Mg}$, it takes a $\mathrm{PP} / \mathrm{PO}_{4}$ of 0.03 to produce $\mathrm{ACP}$, while in the presence of magnesium $(\mathrm{Mg} / \mathrm{Ca}=0.1)$, the $\mathrm{PP} / \mathrm{PO}_{4}$ molar ratio required is reduced to 0.02 .

As stated previously, Ferguson et al. ${ }^{50}$ described quantitatively the effect of carbonate on the precipitation rate of phosphate. They found that the rate is inversely proportional to the carbonate concentration.

With respect to the solubility of apatites, decreasing crystallinity increases the solubility of the compounds. ${ }^{62,68}$ Menar and Jenkins ${ }^{57}$ assumed that the gradual increase in the TCP activity product is caused by carbonate inclusion in the calcium phosphate solid. The solubility products found in amorphous or partially crystalline systems are apparent solubility products. When the substitutions in the calcium structure are significant, it may be meaningless to relate the solubility to HAP because the precipitation product is rather a new compound or a solid solution.

From the work of Legeros et al., ${ }^{61}$ it is interesting to note that $\mathrm{Zn}^{2+}, \mathrm{Al}^{3+}$, and $\mathrm{Fe}^{2+}$ suppress apatite crystal growth and stabilize $\beta$-TCP with significant incorporation of 
the ions in the solid phase. This is in accordance with the theory put forward by Arvin and Pedersen ${ }^{70}$ and Arvin and Skaarup ${ }^{71}$ that when iron or aluminum is present, calcium-iron or calcium-aluminum phosphates is formed.

The formation of calcium-iron and calcium-aluminum phosphate may be of considerable practical importance. Even when iron, aluminum, or zinc are not added consciously, the metals may be in the wastewater from industrial sources. It should be emphasized that the structure of calcium-iron phosphates and calcium-aluminum phosphates still remains to be resolved. Adsorption phenomena may be involved together with precipitation.

Finally, it is important to note that fluoride, $\mathrm{F}^{-}$, promotes crystal growth of apatities and accordingly decreases the solubility of the precipitate. Also the crystallinity of carbonate apatites are increased, but the incorporation of carbonate is not affected..$^{59,62}$ Fluoride has a significant effect even at a concentration level at a few parts per million..$^{51,69,72}$

\section{Experimental Observations in Biological Phosphorus Removal Systems}

Controlled experiments from which it is possible to quantify the relative contribution of biological and chemical $P$ fixation have not yet been performed. The only data available which can give a qualitative estimate of the mineral $P$ fraction are influent/ effluent concentrations of cations and $\mathrm{P}$ and/or measurements of cations and $\mathrm{P}$ in the sludge. Very often such minimum data are not even available. The following sections will present experimental observations in biological $\mathrm{P}$ removal systems related to chemical precipitation.

\section{The Rilling Plant, San Antonio, Texas}

The Rilling Plant is a conventional activated sludge plant without nitrification. The mixed liquor moves through aeration tanks in a plug flow manner with an actual detention time of approximately $6 \mathrm{hr}$ (based on influent plus return sludge). ${ }^{35}$

The anaerobic phosphate release in the first half of the aeration tanks is up to $30 \mathrm{mg}$ of $\mathrm{P}$ per liter, and the anaerobic $\mathrm{P}$-release studies in batch systems performed by Wells ${ }^{36,73}$ indicate biological $P$ removal. A simultaneous chemical precipitation is indicated by both the removal of cations and the sludge composition (Tables 4 and 5). From these tables it appears that the maximum mineral $\mathrm{P}$ removal may be roughly $50 \%$ of the total removal.

The presence of mineral-bound phosphate can explain results obtained by Wells ${ }^{73}$ and Menar and Jenkins ${ }^{74}$ in relation to the effect of $\mathrm{pH}$ variations. The occurrence of chemical precipitation is furthermore confirmed by the presence of mineralized phosphate on the air diffusion tubes. ${ }^{73}$

Chemical precipitation in the Rilling Plant is favored by the fact that the phosphate concentration increases up to $30 \mathrm{mg}$ of $\mathrm{P}$ per liter in the anaerobic part of the aeration tank, the $\mathrm{pH}$ in the effluent is 7.7 to 7.9 and the calcium concentration is relatively high, 60 to $90 \mathrm{mg} / \ell$. The anaerobic $P$ release may be the driving force for chemical precipitation as described in Section IV.A.

\section{The Baltimore Plant, Maryland}

The Baltimore Plant has the same plug flow configuration as the Rilling Plant. The actual detention time in the aeration tanks is also similar - 4.5 to $5 \mathrm{hr}^{37,75}$ Also, in the Baltimore plant phosphate is released in the front end of the aeration tank when the oxygen concentration in the first half of the tank is kept near $0 \mathrm{mg} / \ell$ (Figure 10). This behavioral pattern is consistent with observations where enhanced biological removal is observed.

No data on sludge composition are given for this plant. The cation concentration in the primary effluent is (milligrams per liter) calcium, 25.3; magnesium, 14.1; iron, 3.2; 


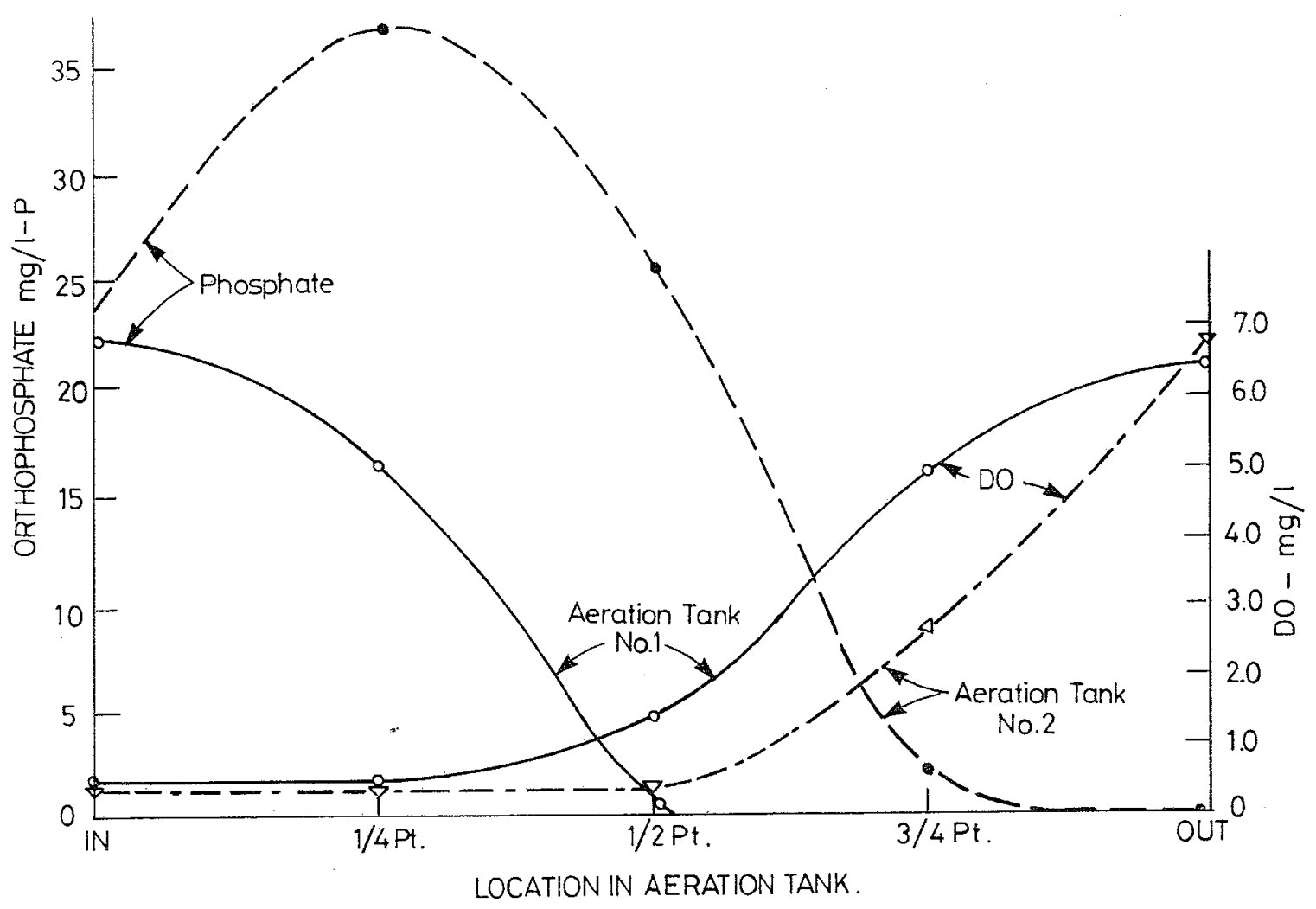

FIGURE 10. Profiles of orthophosphate and dissolved oxygen in the aeration tank of the Baltimore Plant. (From Scalf, M. R., Pfeffer, F. M., Lively, L. D., Witherow, J. F., and Priesing, C. P., ASCE J. Sanit. Eng. Div., 95, 817, 1969. With permission.)

\section{The Hyperion Plant, Los Angeles, California}

The Hyperion Plant is a conventional, activated sludge plant with a sludge age between 7 and 10 days and a nominal detention time of 8 to $9 \mathrm{hr} .{ }^{77}$ The aeration tank appears to be a plug-flow type.

Unlike the Rilling and Baltimore Plants, the optimum $P$ removal, $96 \%$, from 9.9 to $0.4 \mathrm{mg}$ of $\mathrm{P}$ per liter, is obtained at a relatively high aeration rate. The profiles of $\mathrm{PO}_{4}^{-}$ $\mathrm{P}, \mathrm{NO}_{3}-\mathrm{N}$, and $\mathrm{pH}$ varied as shown in Figure 11. In this case, the phosphate concentration decreases through the reactor and no initial $P$ release is observed. Lowering the aeration rate from 1.81 to $1.66 \mathrm{ft}^{3} /$ gal decreased the $\mathrm{P}$-removal efficiency to $40 \%$. At the same time, nitrification stopped and the $\mathrm{pH}$ dropped from 7.2 to 6.9. This behavioral pattern points towards chemical pecipitation as the major P-removal mechanism in this specific plant. The removal of cations supports this view (refer to Table 6).

\section{University of Cape Town Pilot Plant, South Africa}

The work done by Hoffmann and Marais ${ }^{58}$ has focused on the relative significance of biological $\mathrm{P}$ removal and chemical $P$ precipitation in several modifications of activated sludge nitrification/denitrification pilot plants. They concluded that precipitation occurred, but the relative contribution to the overall $P$ removal was small, 1 to 1.5 $\mathrm{mg}$ of $\mathrm{P}$ per liter out of a total removal of 5 to $9 \mathrm{mg}$ of $\mathrm{P}$ per liter. The conditions were influent, 10 to $11 \mathrm{mg}$ of $\mathrm{P}$ per liter; effluent, 1 to $7 \mathrm{mg}$ of $\mathrm{P}$ per liter; $\mathrm{pH}, 7$; and $\mathrm{Ca}^{2+}$ $=35 \mathrm{mg} / \ell$. The precipitate is expected to be a calcium phosphate because calcium removal took place, but chemical analyses of the sludge were not reported.

The authors observed that most of the calcium phosphate removal occurred in the anoxic reactor simultaneously with a phosphate release. This supports the view that biological $\mathrm{P}$ stripping accelerates $\mathrm{P}$ precipitation. The generally low $\mathrm{P}$ precipitation can 


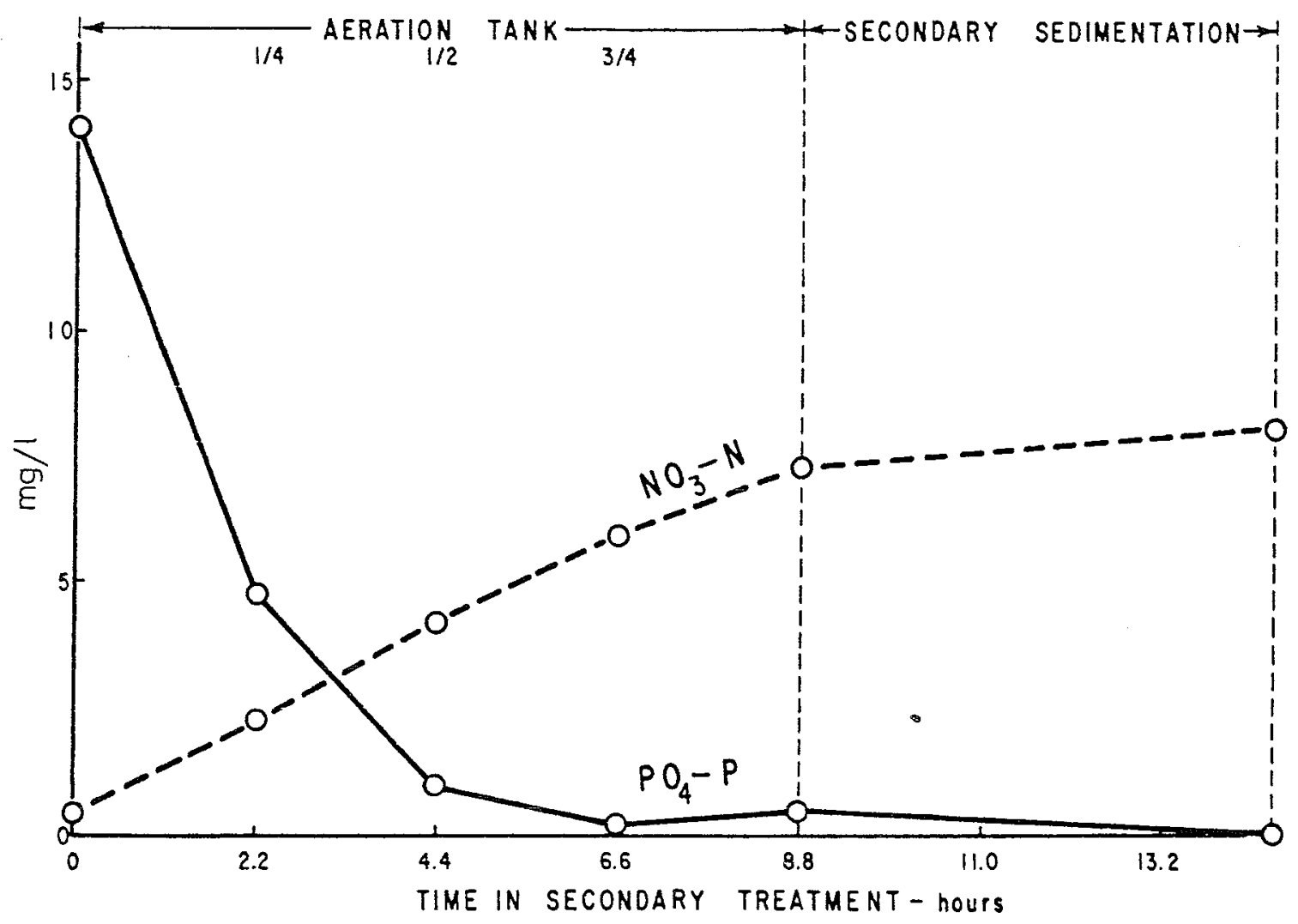

FIGURE 11. Profiles of ortho-phosphate and nitrate in the aeration tank and sedimentation tank of the Hyperion Plant. (From Bargman, R. D., Betz, J. M., and Garber, W. F., Adv. Water Pollut. Res., San Francisco and Hawaii, I-14/1-17, 1970.).

Table 6

CALCULATION OF MAXIMUM POTENTIAL P REMOVAL BY CATIONS IN THE HYPERION PLANT (DATA FROM APRIL TO JULY 1969) ${ }^{77}$

$\begin{array}{lccccc}\text { Cation } & \begin{array}{c}\text { Influent } \\ \text { concentration } \\ (\mathrm{mg} / \ell)\end{array} & \begin{array}{c}\text { Effluent } \\ \text { concentration } \\ (\mathrm{g} / \ell)\end{array} & \begin{array}{c}\text { Cation } \\ \text { removal } \\ (\mathrm{mg} / \ell)\end{array} & \begin{array}{c}\text { Cation/P } \\ \text { molar ratio }\end{array} & \begin{array}{c}\text { P removal } \\ \text { by cations } \\ (\mathrm{mg} \mathrm{P} / \boldsymbol{l})\end{array} \\ \mathrm{Ca} & 71.2 & 64.8 & 6.4 & 1.5 & 3.3 \\ \mathrm{Fe} & 2.8 & 0.2 & 2.6 & 1 & 1.4 \\ \mathrm{Al} & 2.4 & 0.2 & 2.2 & 1 & 2.5 \\ \mathrm{Zn} & 1.4 & 0.3 & 1.1 & 1.5 & 0.3 \\ & & & & & 6.5 \\ \text { Maximum P removal by cations (mg P/l) } & & & & 9.5\end{array}$

be explained by the relatively low $\mathrm{pH}$ prevailing in the bulk liquids, often around $\mathrm{pH}$ 7 , the low calcium concentration; 30 to $35 \mathrm{mg} / \ell$, and the small $P$ release in the anoxic reactor; in several experiments, even a net decrease was observed.

The reported data give insufficient background to evaluate the feasibility of biofilm precipitation, e.g., alkalinity data are not given. However, the low calcium concentrations are not in favor of this phenomenon.

It is important to emphasize the following observation made by the investigators. Measurements of the calcium removal in treatment plants are only valid if it is meas- 


\section{Table 7}

\section{ANALYSIS OF ANAEROBIC SEDIMENTS AND WALL S C R A P I N G S F R O M CLARIFIERS}

\begin{tabular}{|c|c|}
\hline Organic matter & $45.8 \%$ \\
\hline Potassium & Trace \\
\hline Sodium & $0.3 \%$ \\
\hline Calcium & $4.1 \%$ \\
\hline Iron & $8.0 \%$ \\
\hline Aluminum & $0.05 \%$ \\
\hline $\begin{array}{l}\text { Soluble phosphate (as } \mathrm{PO}_{4} \text { ) ex- } \\
\text { cluding organic and condensed } \\
\text { phosphates }\end{array}$ & $5.0 \%$ \\
\hline $\mathrm{SiO}_{2}$ & $31.3 \%$ \\
\hline $\begin{array}{l}\text { From Kerdachi, D. A.and Roberts, } \\
\text { Further developments in the under } \\
\text { of phosphate removal at Umhlatuz } \\
\text { per presented at Southern Africa B } \\
\text { East London Conf., London, 1983, } \\
\text { permission. }\end{array}$ & $\begin{array}{l}\text { M. R., } \\
\text { standing } \\
\text { ana, pa- } \\
\text { ranch of } \\
6 . \text { With }\end{array}$ \\
\hline
\end{tabular}

ured as the difference between the total $\mathrm{Ca}^{2+}$ in the influent and the soluble $\mathrm{Ca}^{2+}$ in the effluent. The suspended (organic) matter in the influent contains a significant amount of calcium, and this is liberated through the hydrolyzation processes in the plant.

\section{The Umhlatuzana Plant, South Africa}

The Umhlatuzana Plant is a very low-loaded activated sludge plant without primary sedimentation. ${ }^{52,53}$ Surprisingly, the $P$ removal improved from 60 to $94 \%$ (influent total: P, $10.5 \mathrm{mg}$ of $\mathrm{P}$ per liter) when the sludge age increased from 8 to 69 days. Based on calculations of the relative biological and chemical $\mathrm{P}$ removal, the authors concluded that chemical removal (natural extracellular precipitation and adsorption) must have accounted for a third of the $92 \% \mathrm{P}$ removal with a sludge age of 38 days and about half of the $94 \% \mathrm{P}$ removal with a sludge age of 69 days.

As described in Section IV.A, the precipitation product was assumed to be a calcium ferrous phosphate compound. Analysis of the cation and P content of activated sludge samples has not been presented, but Table 7 may give some indication of the composition. These figures should be seen in relation to the influent cation and $P$ concentrations (milligrams per liter): $\mathrm{Ca}, 28 ; \mathrm{Mg}, 12 ; \mathrm{Fe}, 3$; total $\mathrm{P}, 10.5$; and soluble $\mathrm{P}, 5$.

It is interesting to note that precipitation appears to play a role despite the soft water and the $\mathrm{pH}$ around neutrality. The iron content in the sewage is most likely the background for this precipitation.

\section{The Goudkoppies Plant, South Africa}

The research associated with the full-scale Badenpho plants at Johannesburg has clearly demonstrated the biological phosphate removal mechanism. ${ }^{13.25-27}$ A certain role of chemical precipitation is indicated from measurements on the water and sludge phase at the Goudkoppies plant (Tables 8 and 9).

The maximum potential $P$ removal is approximately three times the actual $P$ removal in the case of COD supplementation from a yeast factory. Without COD supplementation, the maximum potential $\mathrm{P}$ removal is about $50 \%$. 
Table 8

P REMOVAL AT THE GOUDKOPPIES PLANT - CALCULATION OF
MAXIMUM POTENTIAL CHEMICAL PHOSPHATE REMOVAL WITH
CATIONS AND COMPARISON WITH ACTUAL REMOVALS ${ }^{78.79}$

\begin{tabular}{|c|c|c|c|c|c|c|c|c|c|c|}
\hline \multirow[b]{3}{*}{ Substance } & \multirow{3}{*}{$\begin{array}{l}\text { Metal/P } \\
\text { molar } \\
\text { ratio }\end{array}$} & \multicolumn{3}{|c|}{ Good P removal } & \multicolumn{3}{|c|}{$\begin{array}{l}\text { Below optimum P re- } \\
\text { moval }\end{array}$} & \multicolumn{3}{|c|}{$\begin{array}{l}\text { Sewage supplemented } \\
\text { with extra } 37 \% \text { COD } \\
\text { from yeast industry }\end{array}$} \\
\hline & & \multicolumn{2}{|c|}{$\begin{array}{l}\text { Conc } \\
(\mathrm{mg} / \mathrm{l})\end{array}$} & \multirow{2}{*}{$\begin{array}{c}\text { Max } P \\
\text { removal } \\
(\mathrm{mg} / \mathrm{l})\end{array}$} & \multicolumn{2}{|c|}{$\begin{array}{c}\text { Conc } \\
(\mathrm{mg} / \ell)\end{array}$} & \multirow{2}{*}{$\begin{array}{c}\text { Max } P \\
\text { removal } \\
(\mathrm{mg} / \ell)\end{array}$} & \multicolumn{2}{|c|}{$\begin{array}{c}\text { Conc } \\
(\mathrm{mg} / \mathrm{l})\end{array}$} & \multirow{2}{*}{$\begin{array}{l}\text { Max } P \\
\text { removal } \\
(\mathrm{mg} / \mathrm{l})\end{array}$} \\
\hline & & In & Out & & In & Out & & In & Out & \\
\hline $\mathrm{Ca}$ & 1.5 & 47 & 45 & 1.0 & 58 & 56 & 1.0 & 88 & 65 & 11.9 \\
\hline $\mathrm{Mg}$ & 1.5 & 20 & 18 & 1.7 & 26 & 24 & 1.7 & 29 & 23 & 5.2 \\
\hline $\mathrm{Fe}$ & 1 & 1.6 & 0.6 & 0.6 & 2.3 & 0.6 & 0.9 & 3.9 & 0.8 & 1.7 \\
\hline $\mathrm{Al}$ & 1 & 0.5 & 0.2 & 0.3 & 0.7 & 0.1 & 0.7 & 2.4 & 0.2 & 2.5 \\
\hline $\mathrm{Zn}$ & 1.5 & - & - & - & - & - & - & 3.3 & 0.3 & 1.0 \\
\hline \multicolumn{4}{|c|}{ Maximum $P$ removal (mg $P / \ell$ ) } & 3.6 & & & 4.3 & & & 22.3 \\
\hline \multicolumn{4}{|c|}{ Actual P removal (mg P/l) } & 6.0 & & & 4.2 & & & 6.7 \\
\hline
\end{tabular}

Table 9

SLUDGE DATA FROM THE GOUDKOPPIES PLANT CALCULATION OF MAXIMUM POTENTIAL P FIXATION BY CATIONS IN THE SLUDGE ${ }^{78,79}$

\begin{tabular}{|c|c|c|c|c|c|}
\hline \multirow[b]{2}{*}{ Cation } & \multicolumn{2}{|c|}{$\begin{array}{c}\text { Conc in sludge } \\
(\% \text { of } \mathrm{SS})\end{array}$} & \multirow[b]{2}{*}{$\begin{array}{c}\text { Metal/P } \\
\text { molar } \\
\text { ratio }\end{array}$} & \multicolumn{2}{|c|}{$\begin{array}{c}\text { Max P fixation } \\
\% \text { of SS }\end{array}$} \\
\hline & $\begin{array}{c}\text { Good } \\
\text { operation }\end{array}$ & $\begin{array}{c}\text { Bad } \\
\text { operation }\end{array}$ & & $\begin{array}{c}\text { Good } \\
\text { operation }\end{array}$ & $\begin{array}{c}\text { Bad } \\
\text { operation }\end{array}$ \\
\hline $\mathrm{Ca}$ & 1.2 & 1.4 & 1.5 & 0.6 & 0.7 \\
\hline $\mathrm{Mg}$ & 0.8 & 0.6 & 1.5 & 0.7 & 0.5 \\
\hline $\mathrm{Fe}$ & 1.1 & 1.3 & 1.0 & 0.6 & 0.7 \\
\hline $\mathrm{Al}$ & 0.2 & 0.2 & 1.0 & 0.2 & 0.2 \\
\hline \multicolumn{4}{|c|}{ Maximum $P$ fixation by cations $(\% \mathrm{P})$} & 2.1 & 2.1 \\
\hline \multicolumn{4}{|c|}{ Actual $\mathrm{P}$ in sludge $(\% \mathrm{P})$} & 4.8 & 3.8 \\
\hline
\end{tabular}

\section{Biodenitro and Biodenipho Plants, Denmark}

Data on sludge composition have been obtained from the full-scale Biodenitro plant in Frederikssund and the pilot Biodenipho plant in Lyngby. ${ }^{41,48}$ Both the total content of cations and $\mathrm{P}$ as well as the content in acid and alkaline extracts were obtained. The extraction procedure described by Furumai and Ohgaki ${ }^{80}$ was applied.

In Table 10 the maximum potential fixation of $P$ by cations is calculated. Tables 11 and 12 show the results from extractions with $\mathrm{NH}_{4} \mathrm{Cl}(0.5 \mathrm{M}), \mathrm{NaOH}(1 \mathrm{~N})$, and $\mathrm{HCl}$ $(1 N)$.

According to the calculations of the maximum potential $P$ fixation, these are similar to the actual $\mathrm{P}$ fixation. However, some of the cations are not $\mathrm{P}$ bound. If one assumes that the mineral $\mathrm{P}$ corresponds to the $\mathrm{PO}_{4}-\mathrm{P}$ fractions, this mineral $\mathrm{P}$ fraction is Biodenitro plant, Frederikssund, $66 \%$ of total sludge P; and Biodenipho plant, Lyngby, $59 \%$ of total sludge P.

It is interesting to note that even though $\mathrm{Mg}^{2+}$ and $\mathrm{K}^{+}$are released during anaerobic $P$ release and substrate uptake, the calcium concentration is simultaneously decreased. ${ }^{41}$ This applies to both the Biodenitro and Biodenipho sludge and may indicate a precipitation reaction mediated by the phosphate release. In the Frederikssund plant, 
Table 10

SLUDGE DATA FROM BIODENITRO AND BIODENIPHO

PLANTS - CALCULATION OF MAXIMUM POTENTIAL P FIXATION BY CATIONS IN THE SLUDGE ${ }^{41,48}$

\begin{tabular}{|c|c|c|c|c|c|}
\hline \multirow[b]{2}{*}{ Cation } & \multicolumn{2}{|c|}{$\begin{array}{l}\text { Conc in sludge } \\
(\% \text { of SS })\end{array}$} & \multirow{2}{*}{$\begin{array}{c}\text { Metal/P } \\
\text { molar } \\
\text { ratio }\end{array}$} & \multicolumn{2}{|c|}{$\begin{array}{l}\text { Max P fixation } \\
(\% \text { of SS })\end{array}$} \\
\hline & Biodenitro & Biodenipho & & Biodenitro & Biodenipho \\
\hline $\mathrm{Ca}$ & 4.3 & 2.5 & 1.5 & 2.2 & 1.3 \\
\hline $\mathrm{Mg}$ & - & 0.7 & 1.5 & - & 0.6 \\
\hline $\mathrm{Fe}$ & 1.2 & 1.0 & 1.0 & 0.7 & 0.6 \\
\hline $\mathrm{Al}$ & 0.2 & 0.6 & 1.0 & 0.2 & 0.7 \\
\hline $\mathrm{Zn}$ & - & 0.2 & 1.5 & - & 0.1 \\
\hline \multicolumn{4}{|c|}{ Maximum $\mathbf{P}$ fixation by cations $(\% \mathrm{P})$} & 3.1 & 3.3 \\
\hline \multicolumn{4}{|c|}{ Actual $P$ in sludge $(\% \mathrm{P})$} & 2.9 & 3.9 \\
\hline
\end{tabular}

Table 11

CHEMICAL ANALYSIS ON RETURN SLUDGE FROM THE BIODENITRO TREATMENT PLANT, FREDERIKSSUND, (VSS, $63 \%$ OF SS)

\begin{tabular}{|c|c|c|c|c|c|}
\hline & \multicolumn{2}{|c|}{$\mathrm{P} \%$ of SS } & \multicolumn{3}{|c|}{$\begin{array}{l}\text { Cation content in } \\
\text { sludge }(\%)\end{array}$} \\
\hline & Total P & $\mathrm{PO}_{4}-\mathrm{P}$ & $\mathrm{Ca}$ & $\mathrm{Fe}$ & $\mathrm{Al}$ \\
\hline $\mathrm{NH}_{4} \mathrm{Cl}$ extract $(0.5 \mathrm{M})$ & 0.4 & 0.3 & 0.7 & 0 & 0 \\
\hline $\mathrm{NaOH}$ extract & 0.8 & 0.5 & 0 & 0.1 & 0.1 \\
\hline $\mathrm{HCl}$ extract & 1.3 & 1.1 & 4.0 & 1.3 & 0.1 \\
\hline Extraction $\div$ residuals & 2.5 & 1.9 & 4.7 & 1.4 & 0.2 \\
\hline $\begin{array}{l}\text { Total content by Kjeldahl Analy- } \\
\text { sis }\end{array}$ & 2.9 & - & 3.9 & 1.0 & - \\
\hline
\end{tabular}

Note: All values are average values of three sludge samples.

From Arvin, E., Water Sci. Technol., 15, 43, 1983. With permission.

Table 12

CHEMICAL ANALYSIS OF SLUDGE FROM THE BIODENIPHO TREATMENT PLANT, LYNGBY

\begin{tabular}{|c|c|c|c|c|c|c|c|}
\hline & \multicolumn{2}{|c|}{$\mathrm{P} \%$ of SS } & \multicolumn{5}{|c|}{ Cation content in sludge $(\%)$} \\
\hline & Total P & $\mathrm{PO}_{4}-\mathrm{P}$ & $\mathrm{Ca}$ & $\mathrm{Mg}$ & $\mathrm{Fe}$ & $\mathrm{Al}$ & $\mathrm{Zn}$ \\
\hline $\mathrm{NH}_{4} \mathrm{Cl}$ extract & - & 0.5 & 0.4 & 0.3 & 0.0 & 0.0 & 0.0 \\
\hline $\mathrm{NaOH}$ extract & - & 0.8 & 0.0 & 0.0 & 0.1 & 0.1 & 0.1 \\
\hline $\mathrm{HCl}$ extract & - & 1.0 & 2.0 & 0.3 & 1.0 & 0.1 & 0.2 \\
\hline$\Sigma$ Extractions $\div$ residuals & - & 2.3 & 2.4 & 0.6 & 1.1 & 0.2 & 0.3 \\
\hline Total content, $\mathrm{HNO}_{3}$ digestion & 3.9 & - & 2.5 & 0.7 & 1.0 & 0.6 & 0.2 \\
\hline
\end{tabular}

From Arvin, E. and Kristensen, G. H., Water Sci. Technol., submitted. With permission.

phosphate is released in the anaerobic phase to $20 \mathrm{mg}$ of $\mathrm{P}$ per liter; in the Biodenipho plant to $30 \mathrm{mg}$ of $\mathrm{P}$ per liter. Other precipitation conditions are favorable: calcium, 100 to $150 \mathrm{mg} / \ell$, and $\mathrm{pH}, 7.5$ to 8 . 


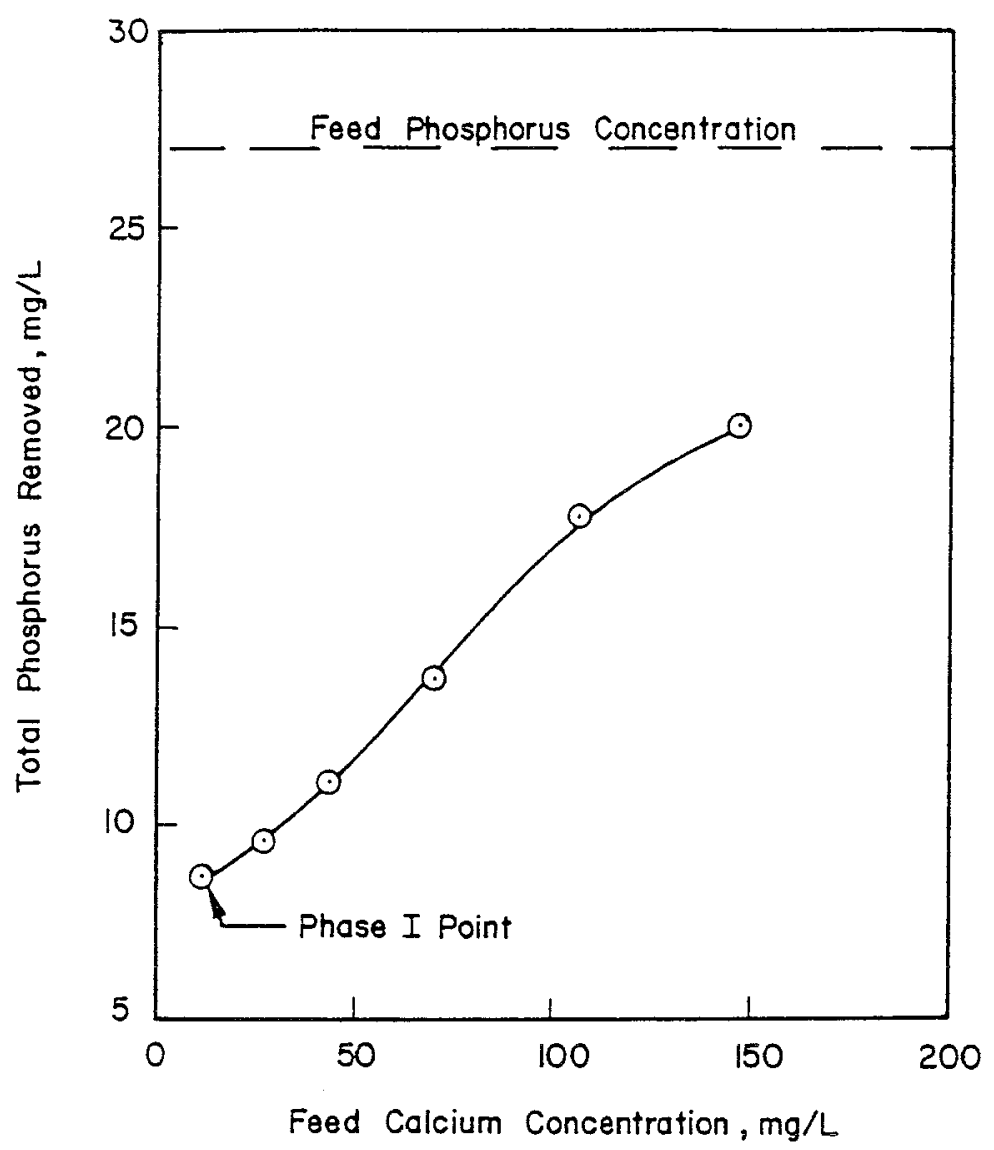

FIGURE 12. P removal vs. influent calcium concentration in a biological P-removal plant. (From Lan, J. C., Benefield, L., and Randall, C. W., Water Res., 17(9), 1193, 1983. With permission.)

\section{8. $P$ Removal in an Anaerobic/Aerobic Pilot Plant, Virginia}

Lan et $a{ }^{81}$ investigated the relative significance of biological and chemical $P$ removal in an anaerobic/aerobic activated sludge pilot plant similar to the A/O process and the Rensink process, Figure 2.

However, the anaerobic tank was $30 \%$ of the total reactor volume and no division of the tanks was applied. The authors concluded that with low calcium wastewater, i.e., $11 \mathrm{mg}$ of $\mathrm{Ca}$ per liter, the primary removal mechanism observed was enhanced biological uptake as calcium phosphate precipitation accounted for only 15 to $27 \%$ of the total $\mathrm{P}$ removal. The wastewater was synthetic, with no iron, aluminum, and zinc present, and with an influent $P$ concentration of 27 of $\mathrm{mg} P$ per liter. The $P$ concentration is two to three times the normal concentration.

By increasing the influent calcium concentration, the $\mathbf{P}$ removal increased as shown in Figure $12(\mathrm{pH}=8$ in aeration tank). The calcium removal increased simultaneously. This increased $\mathrm{P}$ removal is most likely due to calcium phosphate precipitation.

\section{Phosphate Precipitation in a Denitrifying Biofilm}

Phosphate precipitation in a biofilm mediated by biological denitrification has been verified experimentally by Arvin and Kristensen. ${ }^{55}$ In one case the precipitate was identified as a carbonate containing apatitic calcium phosphate. A Ca/P molar ratio of 1.7 supported this. The phosphate content in the biofilm was $9.3 \%$ on a dry weight basis. The normal content is about $2 \%$.

The theoretical and experimental work indicated that the relative phosphate to nitrate molar removal rate increases with the phosphate concentration squared, the cal- 
cium concentration to a power of 1.5 , and is inversely proportional to the alkalinity. The rate also depends on the type of carbon source applied and the type of precipitate formed. Acetate is twice as efficient as methanol.

It was shown experimentally that denitrification in biofilms may lead to a significant phosphate removal, but factors such as precipitation of easily soluble amorphous phosphate phases or filamentous growth on the biofilm surface can render the biofilm precipitation impossible. With background in the theoretical part of this review, amorphous phosphate phases can be suppressed by low ratios of $\mathrm{Mg} / \mathrm{Ca}$, pyro- $\mathrm{P} / \mathrm{PO}_{4}-\mathrm{P}$, and $\mathrm{HCO}_{3} / \mathrm{PO}_{4}$. How to avoid filamentous growth was not identified in the experimental program.

Theoretical calculations and experimental data indicate that phosphate precipitation may occur in flocs in denitrifying systems if biofilm thicknesses greater than approximately $100 \mu \mathrm{m}$ exist. Obviously, the significance of the mechanism has to be experimentally determined in activated sludge systems.

\section{E. Optimization of Chemical Precipitation}

The previous sections have indicated that chemical precipitation occurs to some extent simultaneously with the biological removal of $\mathbf{P}$. It was also mentioned in Section III and will be elaborated on in Section VI that efficient $P$ removal may not always be possible by a pure biological mechanism. With this background it is of interest to know how the chemical precipitation can be improved without disturbing the biological $\mathrm{P}$ removal.

Based on this chapter at least the following possibilities exist:

1. Adding cations: $\mathrm{Fe}, \mathrm{Al}$, or $\mathrm{Ca}$

2. Increasing the $\mathrm{pH}$ in the reactors by adding lime (This also increases the calcium concentration.)

\section{Adding fluoride, $\mathrm{F}^{-}$}

Whether addition of fluoride is feasible seems not to be investigated.

Addition of lime is most likely not as cost effective as adding $\mathrm{Fe}$ and $\mathrm{Al}$ salts. The case studies referred to in this section may indicate that the presence of relatively small amounts of iron and aluminum in the wastewater induce phosphate precipitation with $\mathrm{Fe}, \mathrm{Al}$, and $\mathrm{Ca}$ in the mineral phase. Characterization of this phase remains to be done.

If the natural content of iron and aluminum in the wastewater is insufficient, this can very easily be added in the treatment plant. This simultaneous precipitation technique is well established. However, unlike the conventional process, the dosage of cation is small. There have been no reports indicating that addition of small or moderate amounts of iron or aluminum salts should inhibit biological activity at normal $\mathrm{pH}$ values about 7 . If the chemical dosage implies a $\mathrm{pH}$ decrease to about 6 , nitrification and denitrification are expected to be impaired. However, as long as the chemical dosage is small, the alkalinity reduction from this is also small, and no $\mathrm{pH}$ problems are expected. If, for example, the chemical addition is designed to remove $2 \mathrm{mg}$ of $\mathrm{PO}_{4}-\mathrm{P}$ per liter on top of the biological removal, the alkalinity reduction is as low as $0.1 \mathrm{meq} / \ell$ by $\mathrm{Fe}^{2+}$ addition and $0.2 \mathrm{meq} / \ell$ with $\mathrm{Al}^{3+}$ addition. This is based on a metal to phosphate molar ratio of 1.5 or $67 \%$ efficiency of phosphate precipitation. Rabinowitz and Marais ${ }^{82}$ and Siebritz et al. ${ }^{42}$ found that above an effluent concentration of 1.5 to $2 \mathrm{mg}$ of $\mathrm{PO}_{4}-\mathrm{P}$ per liter, a stoichiometric ratio of $\mathrm{Fe} / \mathrm{P}$ or $\mathrm{Al} / \mathrm{P}$ of 1 is adequate. If an effluent concentration between 0.1 to $2 \mathrm{mg}$ of $\mathrm{PO}_{4}-\mathrm{P}$ per liter is required, the molar ratio must be increased to about 1.7 .

The generality of these dosage requirements mentioned above is questionable. It seems worth investigating, if small amounts of iron and/or aluminum can promote 
significant precipitation of mixed calcium iron and calcium aluminum phosphates. Processes in the anaerobic reactor seem particularly interesting due to the relatively high phosphate concentrations and reactivation of iron from non-P compounds through reduction.

\section{ANALYTICAL CHARACTERIZATION OF PHOSPHORUS FRACTIONS IN SLUDGE}

In order to sort out the relative significance of biological and chemical $\mathrm{P}$ removal in a given biological treatment system, reliable analytical characterization methods must be available. It appears from the previous sections that the analytical techniques must be able to characterize both qualitatively and quantitatively the sludge content of both intracellular polyphosphates and extracellular cation-bound phosphate. This section will review the techniques applied and discuss the limitation of these.

\section{A. Polyphosphates}

In order to find out qualitatively if poly-P is present in the sludge in volutin granules, staining with $1 \%$ methylene blue is normally applied. ${ }^{9,22,25,27}$ However, metachromatic staining is rather nonspecific and is therefore not a sufficient criterion for identification of poly-P. ${ }^{23,24} \mathrm{~A}$ specific technique is the precipitation of lead on poly- $\mathrm{P}$, which is subsequently converted to black lead sulfide. ${ }^{83}$

Another qualitative technique is transmission electron microscopy (TEM). ${ }^{27.83}$ The electron dense poly-P granules appear as hard spherical structures. When the electron beam is focused on the granules they volatilize.

Buchan $^{27}$ did not report on any precipitated phosphate in the sludge. Whether it has not been there or it has dissolved during sample preparation is not known. The fate of precipitated phosphate in the sludge matrix during TEM sample preparation seems not to have been investigated.

Nuclear magnetic resonance (NMR) can be used to identify poly-P from other cell $P$ fractions. ${ }^{84,85}$ As calcium phosphates can also be detected by this technique, NMR may be a valuable tool to distinguish poly-P from cation-bound phosphate.

The usual way to quantify poly-P in sludge is to make extractions with acid and/or alkaline reagents at various temperatures and durations. ${ }^{22-24,86,87} \mathrm{~A}$ rather detailed differentiation of cell $\mathbf{P}$ forms was performed by Fuhs and Chen. ${ }^{22}$ The poly-P is divided into two main fractions, acid-soluble and acid-insoluble poly-P. One is soluble in $5 \%$ trichloracetic acid, TCA $\left(0^{\circ} \mathrm{C}, 45 \mathrm{~min}\right)$; the other is soluble in hot $1 \mathrm{~N} \mathrm{HCl}\left(0^{\circ} \mathrm{C}, 7\right.$ $\min )$. Ahead of the hot-acid treatment lipids and phospholipids are removed by extraction with an ethanol-ether $(3: 1)$ mixture $\left(45^{\circ} \mathrm{C}, 30 \mathrm{~min}\right)$. Other researchers use hot TCA $\left(95^{\circ} \mathrm{C}, 15\right.$ to $\left.30 \mathrm{~min}\right)$ instead of $\mathrm{HCl}_{0}{ }^{46}$

Fuhs and $\mathrm{Chen}^{22}$ refined the extraction further by various pretreatments of the sludge. One of these was treatment with $0.05 \mathrm{M}$ EDTA to release externally bound phosphate. The result from a batch aeration experiment is shown in Table 1. Some superficial (or chemical) fixation of phosphate took place as indicated by the solubilization of $\mathbf{P}$ with EDTA.

An alternative procedure to the acid extraction methods is based on digestion of the cells with alkaline sodium hypochlorite. ${ }^{23}$ This method was used by Fukase et al..$^{32}$ in their experiments with biological P removal. From their experiments still another alternative appears, a biological poly-P characterization method: soluble organic matter, acetate or glucose, is added in such an amount that organic matter is not limiting for the phosphate release. In this way virtually all poly-P is released. An obvious limitation to this procedure is that cationic $\mathrm{P}$ refixation of released phosphate must not be of significance. 


\section{B. Cationic Bound Phosphate}

Appropriate methods to identify cationic bound phosphate fractions from organic bound $\mathrm{P}$ fractions, in particular poly-P, seems not to be investigated in relation to activated sludge. In a somewhat related area, sediment $P$ fractionation, the methodologies first developed in soil science ${ }^{88,89}$ have been applied and further developed. ${ }^{80,90-92}$ In the last procedure both ortho-phosphate and total $\mathrm{P}$ are determined in the $\mathrm{NaOH}$ and $\mathrm{HCl}$ extracts (performed at $\left.20^{\circ} \mathrm{C}\right): 0.5 \mathrm{MNH}_{4} \mathrm{Cl}(30 \mathrm{~min}), 1 \mathrm{~N} \mathrm{NaOH}(20 \mathrm{hr}$ ), and $1 \mathrm{~N} \mathrm{HCl}(20 \mathrm{hr})$. The organic bound $\mathrm{P}$ in each fraction can then be determined by difference between total $P$ and ortho-P.

Hieltjes and Lijklema ${ }^{91}$ used the same reagents at slightly different concentrations, $\mathrm{NaOH} 0.1 \mathrm{~N}$ and $\mathrm{HCl} 0.5 \mathrm{~N}$. They concuded that this extraction procedure was preferable compared to extractions with $\mathrm{NaOH}$ and subsequently citrate, dithonite, and bicarbonate as proposed by Williams et al. ${ }^{93}$ in relation to separation of calcium-bound and iron-aluminum-bound phosphates.

It was shown with samples of pure calcium, iron, and aluminum phosphates by both Furumai and Ohgaki ${ }^{80}$ and Hieltjes and Lijklema ${ }^{91}$ that only about $5 \%$ of the phosphate compounds dissolved in $\mathrm{NH}_{4} \mathrm{Cl}$. $\mathrm{NaOH}$ dissolved the iron and aluminum phosphates, but no calcium phosphate, and $\mathrm{HCl}$ dissolved all these phosphates.

A reservation with respect to the procedure is that the distinction between calciumbound phosphate on one side and iron-aluminum-bound phosphate on the other side is misleading if mixed calcium, iron, and aluminum phosphates actually form, (see Section IV). Furthermore, it is a question of how much organic bound P, particularly poly-P, is hydrolyzed during the extractions and accordingly misinterpreted as inorganic-bound phosphate. The experiments by Fukase et al. ${ }^{32}$ may give an answer to this. They extracted high polyphosphate-containing sludge with $1 \mathrm{NNaOH}$ and $1 \mathrm{NHCl}$ at $20^{\circ} \mathrm{C}: 90 \%$ of the total sludge $\mathrm{P}$ was extracted with $1 \mathrm{~N} \mathrm{NaOH}$ in few hours and $40 \%$ of the sludge $\mathrm{P}$ was extracted with $1 \mathrm{NHCl}$ in $7 \mathrm{hr}$. Only 6 to $7 \%$ of this came out as ortho-P, which indicates that within the time space above very little poly-P and organic $P$ compounds are hydrolyzed. Whether this is true also after $20 \mathrm{hr}$ is not known, but judged from the horizontal shape of the curve it may be.

\section{Status for Analytical Characterization of Sludge}

There have obviously been no research projects specifically dealing with sludge characterization from biological P-removal plants. In particular, reliable methods to distinguish organic bound poly-P from precipitated $\mathrm{P}$ are strongly needed. This will enable determination of the relative significance of biological and chemical $P$ removal in a specific plant. It is not possible presently to indicate the magnitude of the systematic errors in the methods to differentiate these two $\mathrm{P}$ fractions.

\section{PROCESS DESIGN}

When the effluent quality has been specified, the process design for a given biological $P$ removal process should answer among others the following questions:

1. Reactor volumes and their physical design

2. Sludge concentrations in reactors and sludge production

3. Recycle flows and for alternating processes aeration/nonaeration periods

4. Oxygen requirements and oxygen concentration limits in aeration $\operatorname{tank}(\mathrm{s})$

5. Sludge handling and disposal

6. Primary clarification; size and shape of clarifiers

7. Size, shape, filter medium, operating mode, etc. of secondary filters, if needed 
Table 13

EFFLUENT SUSPENDED

\section{PHOSPHORUS CONCENTRATION VS. EFFLUENT SUSPENDED SOLIDS AND SLUDGE P CONTENT}

\begin{tabular}{|c|c|c|c|c|c|}
\hline \multirow{2}{*}{$\begin{array}{c}\text { Sludge } P \\
\text { content } \\
(\% \mathrm{P})\end{array}$} & \multicolumn{5}{|c|}{$\begin{array}{l}\text { Effluent suspended solids } \\
\qquad(\mathrm{mg} / \mathrm{l})\end{array}$} \\
\hline & 2 & 5 & 10 & 20 & 30 \\
\hline 1 & 0.04 & 0.1 & 0.2 & 0.4 & 0.6 \\
\hline 2 & 0.06 & 0.15 & 0.3 & 0.6 & 0.9 \\
\hline 3 & 0.08 & 0.2 & 0.4 & 0.8 & 1.2 \\
\hline 4 & 0.10 & 0.25 & 0.5 & 1.0 & 1.5 \\
\hline 5 & 0.12 & 0.3 & 0.6 & 1.2 & 1.8 \\
\hline & Filtra & & & & \\
\hline
\end{tabular}

Very often, in practice, rather simple design procedures are applied based on rules at thumb: detention times, sludge age, etc. With respect to reactor design, i.e., specification of reactor volumes, sludge concentration, recycle flows, oxygen requirements, etc., more refined methods are emerging. Such methods are based on the process model, taking into account the specific nature of the wastewater, which may vary considerably in composition from place to place. In the following, only design aspects pertinent to achieve $P$ removal will be dealt with.

Whether one or the other design procedures is applied, it is normally desirable to perform pilot plant studies to verify the design, i.e., that it is actually possible to meet the effluent standards. Pilot plant studies also enable the determination of realistic kinetic constants, etc., so that safety factors can be reduced.

An important question in relation to biological $P$ removal is whether effluent filtration is needed. The problem is that the sludge $P$ content from such processes may be higher compared to conventional biological processes. Table 13 shows the effluent suspended $\mathrm{P}$ concentration vs. suspended solids and sludge $\mathrm{P}$ content.

Conventional activated sludge processes have sludge $P$ contents of 1.5 to $3 \%$, sidestream processes (PhoStrip) from 3 to $4 \% \mathrm{P}$, and mainstream processes of 3.5 to $6 \%$ $P$. It appears from Table 13 that without filtration the effluent suspended $P$ concentration (from sidestream and mainstream processes) may well be 0.5 to $1 \mathrm{mg}$ of $P$ per liter or even higher. With effluent filtration this can be reduced to 0.1 to $0.2 \mathrm{mg}$ of $\mathrm{P}$ per liter. As the soluble effluent $P$ concentration is often between 0.5 to $1 \mathrm{mg}$ of $\mathrm{P}$ per liter, it is obvious that maintaining a total effluent $P$ concentration below, say, $1 \mathrm{mg}$ of $\mathrm{P}$ per liter on a consistent basis is hardly possible without filtration. The problems with mainstream processes are probably worse compared to sidestream processes.

\section{A. Main Stream Processes}

Flow diagrams and working principles are explained in Section II.B. A major design consideration is whether nitrogen removal is needed. If nitrification is necessary denitrification must also be performed because nitrate in the return sludge to the anaerobic reactor inhibits $P$ removal. It is not always possible to obtain efficient biological $P$ and nitrogen removal at the same time. If this is true, the designer must decide whether $P$ or nitrogen removal is most important for the recipient. 


\section{Reactor Design Based on Conventional Parameters \\ a. Without Nitrogen Removal}

Table 14 summarizes operating experience giving optimal biological $\mathrm{P}$ removal. With $P$ concentrations in the primary sewage of 8 to $10 \mathrm{mg}$ of $\mathrm{P}$ per liter, soluble effluent $\mathrm{P}$ concentrations of 0.5 to $1 \mathrm{mg}$ of $\mathrm{PO}_{4}-\mathrm{P}$ per liter were obtained. ${ }^{6,7.35 .37 .77}$ This corresponds to specific removals $\left(\triangle \mathrm{P} / \triangle B \mathrm{BOD}_{5}\right)$ of 0.04 to 0.06 . At influent values of $18 \mathrm{mg}$ of $\mathrm{P}$ per liter, the soluble effluent $\mathrm{P}$ concentrations were 2 to $4 \mathrm{mg}$ of $\mathrm{PO}_{4}-\mathrm{P}$ per liter. Here the $\triangle \mathrm{P} / \triangle \mathrm{BOD}_{5}$ removal ratio was 0.05 and $0.08 .^{6.9}$

The upper sludge load $(\mathrm{F} / \mathrm{M})$ limit to obtain good $\mathrm{P}$ removals appears to be $0.7 \mathrm{~kg}$ $\mathrm{BOD}_{5} / \mathrm{MLVSS} /$ day. Surprisingly enough, Sell et al. ${ }^{8}$ state that the $\mathrm{P}$ removal is better at $5^{\circ} \mathrm{C}$ compared to 10 and $15^{\circ} \mathrm{C}$. The effect of temperature on biological $\mathrm{P}$ removal has not been investigated by other researchers.

To obtain optimum $P$ removal, the surplus sludge from primary and secondary clarifiers must be concentrated by dissolved air flotation and subsequently disposed on land burned or stabilized by lime. If anaerobic digestion is applied, the supernatant from dewatering processes must not be returned to the main stream unless $P$ is removed by chemical precipitation. It is also important to avoid $\mathrm{P}$ leakage from the sludge to the supernatant in the secondary clarifier.

The work by Sell et al. ${ }^{8}$ and Rensink et al. ${ }^{9}$ shows that a nominal anaerobic detention time (based on influent flow) of 0.5 to $1 \mathrm{hr}$ is sufficient for soluble organic substrate uptake. This is indeed a fast uptake. It is interesting that phosphate release continues after completion of substrate uptake (Figure 6). It is not yet clear if it has any function to continue the anaerobic period after the point where soluble organic matter is removed. The design data given by Hong et al. ${ }^{6}$ and Deakyne ${ }^{7}$ (Table 14) may suggest that the answer is no.

Hong et al. ${ }^{6}$ introduced design criteria in addition to the sludge loads and retention times. These refer to the influent wastewater characteristics: the influent soluble BOD 5 to the influent soluble $P$ should be $>10$. A theoretical background for this was not specified by the authors. Qualitatively, there seems to be some justification for this rule of thumb. The soluble $P$ is roughly the $P$ fraction in the influent which the $P$ accumulating bacteria must remove. The soluble $\mathrm{BOD}_{5}$ may roughly be the substrate which the $\mathrm{P}$ accumulators absorb and accordingly use for growth. There must naturally be a minimum population of $P$ accumulators to remove a certain amount of soluble $P$ and this may suggest the minimum soluble BOD/P ratio. Further insight in process mechanisms and process models will most likely refine these design criteria. Anyhow, it appears to be a move to supplement conventional reactor design criteria with criteria based influent wastewater. In this regard, the design parameter, $\mathrm{F}_{s} / \mathrm{M}$, sludge load based on soluble $\mathrm{BOD}_{5}$, suggested by Hong et al. ${ }^{6}$ may also be valuable. Based on this parameter, the work by Sell et al..$^{8}$ indicates that a $\mathrm{F}_{s} / \mathrm{M}$ ratio of about 0.25 day $^{-1}$ is the upper loading rate at $5^{\circ} \mathrm{C}$ (in their experiments they used soluble BOD entirely).

\section{b. With Nitrogen Removal}

Most of the present experience with biological and $\mathrm{P}$ removal systems is related to the Badenpho process(es). The design for nitrogen removal is typically based on an aerobic solids retention time, SRT, to obtain nitrification and denitrification rates in each of the two anoxic reactors to achieve nitrate reduction. ${ }^{94-97}$ Barnard ${ }^{94}$ states that the actual SRT of the system seems to be unimportant for the $\mathrm{P}$ removal. A longer SRT than 25 days may give a sludge stable enough for drying in beds or for disposal on land which would solve the problem of the return flow that may contain high concentrations of $P$.

Efficient $P$ removal requires efficient nitrate removal so that very little nitrate is recycled to the anaerobic reactor. To reach that, Barnard ${ }^{10}$ states a maximum influent 


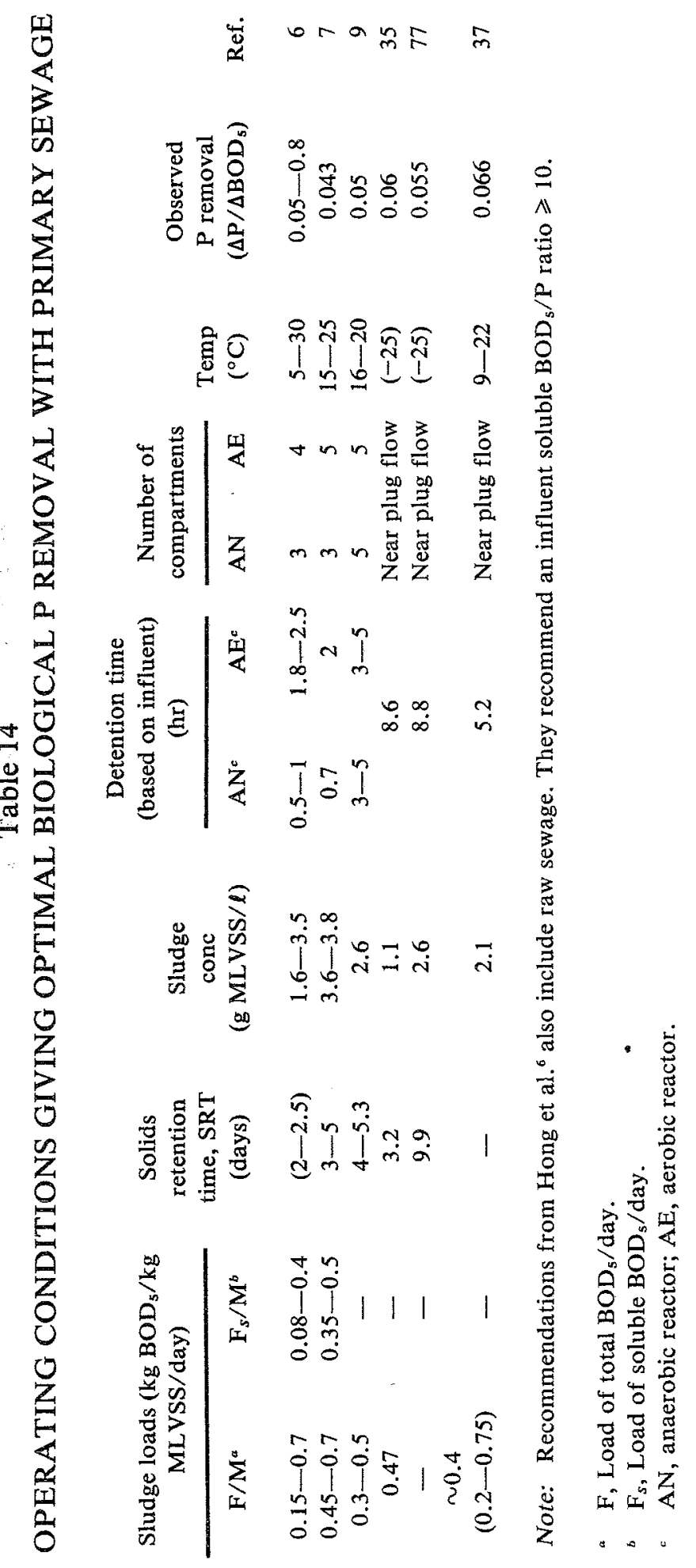


Table 15

NOMINAL DETENTION TIMES IN

THE REACTORS IN 11 SOUTH

AFRICAN BADENPHO PLANTS

\begin{tabular}{lrrr}
\multicolumn{1}{c}{ Basin } & $\begin{array}{c}\text { Min } \\
(\mathrm{hr})\end{array}$ & $\begin{array}{r}\text { Max } \\
(\mathrm{hr})\end{array}$ & $\begin{array}{c}\text { Mean } \\
(\mathrm{hr})\end{array}$ \\
& & & \\
Anaerobic & 0.6 & 1.9 & 1.3 \\
Primary anoxic & 2.2 & 5.2 & 3.2 \\
Aeration & 6.7 & 19.0 & 11.2 \\
Secondary anoxic & 2.2 & 5.7 & 3.3 \\
Reaeration & 0.5 & 1.6 & 1.1 \\
Total & & & \\
& 14.0 & 30.3 & 20.1
\end{tabular}

From Paepcke, B. H., Water Sci. Technol., 15, 219,1983 . With permission.

ratio of total Kjeldahl nitrogen, TKN, to COD of $0.7 \mathrm{mg} \mathrm{N} / \mathrm{mg}$ COD nitrogen/carbon, $T K N / C O D$ ratio, of $0.1 \mathrm{mg}$ of $\mathrm{N}$ per milligram of COD. In addition, the nominal anaerobic detention time (based on influent flow) must be about $1 \mathrm{hr}$. The nominal detention time in the anaerobic, anoxic, and aerobic reactors in South African plants are shown in Table 15. The mixed liquor recycle flow from the first nitrification reactor to the first denitrification reactor is typically four times the design flow rate, and the recycle ratio of activated sludge from the final clarifiers to the anaerobic reactor is normally about one. Ekama et al. ${ }^{14}$ state that complete denitrification can be achieved only for TKN/COD ratios $<0.08 \mathrm{mg}$ of $\mathrm{N}$ per milligram of COD. The authors argue that the UCT process is relatively insensitive against higher TKN/COD ratios. For TKN/COD ratios $>0.14 \mathrm{mg}$ of $\mathrm{N}$ per milligram of COD it is unlikely that excess biological $\mathrm{P}$ removal can be obtained when complete nitrification is obligatory due to the inability to achieve sufficient denitrification.

The results by Paepcke ${ }^{18}$ show that the effluent phosphate concentrations in the South African plants varied between 1 and $15 \mathrm{mg}$ of $\mathrm{PO}_{4}-\mathrm{P}$ per liter. However, these plants are most likely not optimized because the important tool for this came lately with the observation by Marais et $a .^{12}$ that efficient biological $\mathrm{P}$ removal requires a certain amount of biodegradable organics in the sewage. Paepcke ${ }^{18}$ states that some of the plants now exhibit effluent orthophosphate concentrations of about $1 \mathrm{mg}$ of $\mathrm{P}$ per liter. Considering recent data leads to the conclusion that effluent orthophosphate concentrations often lies in the range 1 to $3 \mathrm{mg}$ of $\mathrm{PO}_{4}-\mathrm{P}$ per liter. ${ }^{42,78,79,98.99}$ Calculation of the relative $P$ to $C O D$ removals, $\triangle P / \triangle C O D$, give values in the interval 0.008 to 0.023 . This is the same range as found by Sutton and Jank ${ }^{21}$ for nitrifying systems with and without anoxic-anaerobic reactors.

Design based on conventional parameters of other biological P removal systems with nitrogen removal, the $\mathrm{UCT}$, the Biodenipho, the $\mathrm{A} / \mathrm{O}$, and other processes (see Section II), follows the same lines as described for the Badenpho process. Anaerobic detention times of 1 to $2 \mathrm{hr}$ are also used in these processes, but separation of the reactor in 3 or more separate compartments have been proposed to approximate plug flow..$^{6,42}$ The philosophy is that the substrate uptake is rather a first-order reaction than zero order and therefore a tank in series system is more efficient than a completely mixed system.

\section{Mainstream Reactor Design Based on Process Models}

Conventional reactor design is characterized by not taking the specific composition of the sewage into account. This may give a considerable uncertainty with respect to reactor volumes. 


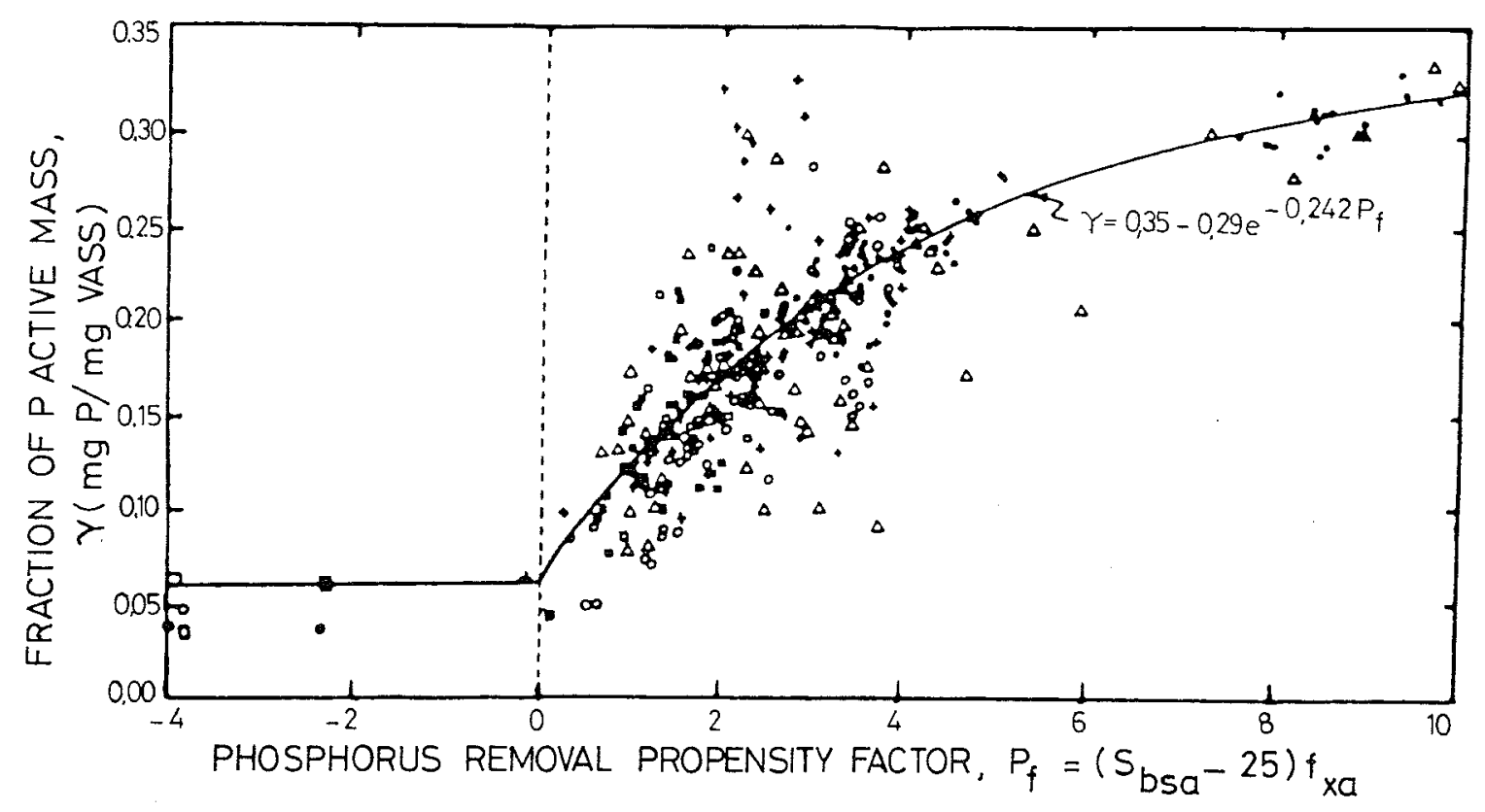

FIGURE 13. P content in the active biomass vs. the P-removal propensity factor, $P_{f}$. (From Siebritz, I. P., Ekama, G. A., and Marais, G. R., Water Sci. Technol., 15, 283, 1983. With permission.)

The conventional way to achieve biological $\mathrm{P}$ removal is to prescribe a 1 to $2 \mathrm{hr}$ anaerobic pretreatment. From this it is not possible to predict quantitatively the biological P removal. The important breakthrough came when the Marais group ${ }^{12,13}$ discovered that the biological $P$ removal can be related to the concentration of readily biodegradable organics in the sewage. Two types of process models for $\mathbf{P}$ removal have been presented, two empirical one ${ }^{13,6}$ and two deterministic ones, based on the growth of poly-P and nonpoly-P accumulating organisms. ${ }^{15,42}$

Hong et al. ${ }^{6}$ have presented a kinetic model for $\mathrm{P}$ release and uptake that seems to fit actually observed $P$ concentrations in the anaerobic and aerobic reactors well. However, the model is difficult to evaluate because the various contents and $P$ contents in the cells are not reported.

\section{a. The Empirical Model}

Siebritz et al. ${ }^{13}$ observed that the propensity to give excess $\mathrm{P}$ removal, $\mathrm{P}_{f}$, appears to be a function only of the magnitude of the readily biodegradable organics in the anaerobic reactor, $S_{b s a}$, above $5 \mathrm{mg}$ of COD per liter, and the magnitude of the anaerobic sludge mass relative to the total mass in the system, $\mathrm{f}_{x a}$ :

$$
P_{f}=\left(S_{b s a}-25\right) \cdot f_{x a}(m g C O D / \ell)
$$

The readily biodegradable concentration $S_{b s a}$ is defined as the concentration in the feed stream to the anaerobic reactor, including the recycle flow, minus the concentration of rapidly biodegradable COD utilized for synthesis of cell material with nitrate (introduced via the influent) serving as electron acceptor. The authors found an empirical relationship between the $\mathrm{P}$ content in the active biomass, $\gamma$, and the propensity factor, $\mathrm{P}_{f}$ (Figure 13). From Figure 13, apparently: (1) there is an upper limit to $\gamma$ of about 0.35 at very high propensity factors and (2) there is a lower limit of about 0.06 at a propensity factor of 0 . Knowing the $\mathrm{P}$ content, $\gamma$, in the active biomass, the total biological $\mathrm{P}$ removal can be calculated.

It appears from Section III that the $\mathrm{P}$ content in pure poly-P is about $30 \% \mathrm{P}$. As poly- $\mathrm{P}$ is only part of the cell mass in poly-P-accumulating organisms and these $\mathrm{P}$ - 
accumulating organisms probably are only part of the total active population, the upper $\gamma$-values in Figure 13 appear unrealistic. It probably reflects insufficiencies in the model systems. However, the model has successfully predicted actual plant performance. $^{42}$

\section{b. The Deterministic Model}

Two preliminary models have been suggested, one by Siebritz et al. ${ }^{42}$ and the other by Vestergaard. ${ }^{15}$ Both are based on the selection concept for poly-P organisms proposed by Marais et al. ${ }^{12}$ (see Section III).

Both groups separate the active biomass in two fractions: poly- $\mathrm{P}$ accumulating organisms and nonpoly-P organisms. Siebritz et al. ${ }^{42}$ assume that the poly-P organisms grow on the rapidly biodegradable COD sequestered in the anaerobic reactor and that this is metabolized in the anoxic and aerobic reactor. This implicitly implies that the poly-P organisms can use nitrate as an electron acceptor.

Vestergaard ${ }^{15}$ assumes that the poly-P organisms grow on the rapidly biodegradable organics sequestered in the anaerobic reactor, but also on the organics hydrolyzed from the suspended biodegradable organic matter in the aerobic reactor in competition with the nonpoly-P organisms. They consider both possibilities that the poly-P organisms can or cannot use nitrate as electron acceptor. Considering the fact that Acinetobacter is a nondenitrifyer, it is likely that the poly-P organisms cannot use nitrate as an electron acceptor and therefore do not grow in the anoxic reactor.

From experiments with the University of Cape Town (UCT) process, Siebritz et al. ${ }^{42}$ obtained the best fit between predicted and measured $\mathrm{P}$ removal for a $\mathrm{P}$ content in the poly-P organisms of $1.1 \mathrm{mg}$ of $\mathrm{P}$ per milligram of cells. Although the predictions of the $P$ removals were good, this cellular $P$ content is obviously not realistic.

Assuming that the poly-P organisms cannot use nitrate as an electron acceptor, that about $60 \%$ of the $\mathrm{P}$ is removed by natural chemical precipitation by cations in the sewage (refer to Section IV), Vestergaard. ${ }^{15}$ found for the Biodenipho process that the poly-P organisms must contain about $3 \% \mathrm{P}$. This is a realistic, but relatively low cellular $\mathbf{P}$ content.

Both models described above are preliminary process models that will be further refined. However, it is likely that future design will be based on such models because it may eventually lead to more reliable results and the implementation on microcomputers will make it easy to apply for both design and process analysis.

\section{B. SideStream Processes}

Flow diagrams and working principles are explained in Section II.A and C. This section deals with design of the PhoStrip process entirely because this is by far the bestdocumented sidestream process.

Like in the mainstream processes, the anaerobic reactor is the key process to obtaining enhanced $\mathrm{P}$ removal. The aeration system and the lime precipitation system are designed by conventional means. If nitrification is required in the aeration tank, this must be designed based on aerobic sludge age like the mainstream processes with nitrification. ${ }^{5}$ Miyamoto-Mills et al. ${ }^{5}$ summarize the design criteria of the $\mathrm{P}$ stripping tank:

\section{Solids Retention Time in P Stripper (SRT)}

A minimum amount of time under anoxic conditions is required for $\mathrm{P}$ to be released into solution.

\section{Elutriation Rate}

Once $\mathrm{P}$ is released to solution, it must be transported to the $\mathrm{P}$ stripper supernatent. This is also accomplished by elutriation, by $\mathrm{P}$-stripper underflow recycle, or by a combination of these. 


\section{Mass of Solids Through P Stripper}

At given P-stripper SRT and elutriation/recycle rates, mass balance considerations require that for a given $P$ removal from the mainstream, a minimum sidestream solids through-put be processed. The authors concluded that elutriation was required for successful operation. P-stripper underflow recycled to the stripper feed stream was less efficient. The following $P$-stripper operating conditions were required for the removal of $P$ in primary sewage from 8 to $10 \mathrm{mg}$ of $P$ per liter to less than $1 \mathrm{mg}$ total $\mathrm{P}$ per liter:

1. P-stripper SRT $>8$ to $10 \mathrm{hr}$. P-stripper elutriation rate $>0.3 \ell / \mathrm{g} \mathrm{SS}$.

2. P-stripper solids through-put (loading) $>100 \mathrm{~g}$ SS per $\mathrm{g}$ of $\mathrm{P}$ to be removed.

SS refers to the solids in the sidestream feed to the $P$ stripper.

Primary effluent was used for elutriation. The reason why primary effluent elutriation is superior to sludge recycle may be that this contains readily biodegradable organic matter, which promotes phosphate release. Temperatures were fairly high; in a period it increased from 24 to $31^{\circ} \mathrm{C}$. The work by Shapiro et al. ${ }^{47}$ indicates that the SRT value must be nearly doubled when the temperature drops $10^{\circ} \mathrm{C}$. Generally the anaerobic SRT in various pilot plants and full-scale plants is 8 to $26 \mathrm{hr} .^{2-5,100}$

Peirano et al., ${ }^{100,101}$ who used sludge recycle for elutriation, presented a somewhat different design procedure. They based it on an empirical relationship between phosphate removal efficiency and the independant parameters:

1. Anaerobic sludge detention time

2. Sludge mass throughout in stripping tank per unit of influent wastewater

3. Supernatant flow in $P$ stripper per unit of sewage flow

\section{OPERATIONAL PROBLEMS}

Even moderate concentrations of suspended matter may be a problem in biological P-removal plants due to the relatively high $\mathrm{P}$ content in the sludge (see Section VI). Effluent filtration should be considered if this is actually a problem. If the soluble effluent $P$ concentration also is too high, this can be reduced by converting the filter to a contact filter with iron salt addition in the filter influent. ${ }^{102}$ Iron sludge from the filter can then be recycled to the anaerobic/aerobic reactors to assist the $\mathrm{P}$ precipitation in the plant. This optimization strategy has not yet been investigated.

Based on the previous sections, operational problems with too high effluent concentrations of soluble $\mathrm{P}$ in mainstream processes may be solved by several other means, in particular:

1. Increasing the concentration of both total and readily biodegradable organics in the sewage

2. Minimizing the amount of oxygen and nitrate to the anaerobic reactor

3. Increasing the size of the anaerobic reactor and subdividing this reactor in several completely mixed tanks to approximate plug flow

4. By adding iron or aluminum salts to the anaerobic reactor

Simultaneous biological and nitrogen removal may give problems due to the inhibiting effect of nitrate in the anaerobic reactor. For a particular plant, nitrate removal can be controlled to a certain extent by adjusting the recycle ratio from the aerobic reactor to the anoxic reactor. This applies to recycle processes (Badenpho, UCT, etc.). 
In alternating processes (Biodenipho), the nitrate removal can be partly controlled by adjusting the aerobic/anaerobic phase length. These control operations are, however, difficult in practice because reliable on-line measuring equipment for nitrate and ammonia is not available. There is obviously a need for development of analytical equipment and control strategies in relation to in-plant recycles or phase length.

In order to increase both the total $\mathrm{BOD}_{5}$ and the readily biodegradable organics to the plant, supplementation of industrial waste should be considered, e.g., waste from breweries, dairies, etc. Supplementation with "young" leachate, where most of the COD is volatile fatty acids, may be particularly efficient. The tendency to introduce pretreatment of the sewage in the factories with anaerobic waste treatment to save energy will certainly in some places reduce the potential for both enhanced biological $P$ removal and biological nitrogen removal.

As explained in Section IV, addition of iron or aluminum salts is a very simple way to control the soluble effluent $P$ concentration. The control is, however, limited by the lack of an on-line method to determine orthophosphate.

Although P-accumulating bacteria seem to work as well at $5^{\circ} \mathrm{C}$ as at 10 and $15^{\circ} \mathrm{C},{ }^{6}$ the general knowledge is so limited that further work in this respect should be performed. A very limited amount of knowledge is also available with respect to the effect of oxygen concentration in the aeration tank. The normal level is in the range 1.5 to 3 $\mathrm{mg}$ of $\mathrm{O}_{2}$ per liter. Too high oxygen concentration is uneconomical and will adversely affect denitrification through recycle flows, etc. If the concentration is too low, $P$ uptake and nitrification may be incomplete and poor settling sludge may develop. ${ }^{14}$

\section{CONCLUSIONS}

1. It is possible selectively to promote the growth of poly-P-accumulating bacteria by introducing an anaerobic fermentation reactor ahead of the aerobic/anoxic reactors.

2. Although the selection mechanism is not yet settled, the following hypothesis explains experimental observations satisfactorily: poly-P-accumulating organisms are able to use the poly-P as an energy source in the anaerobic fermentation reactor to absorb and store (sequester) low molecular organic compounds as PHB or other reserve material. The stored organic carbon is subsequently used for growth of poly-P bacteria in the aerobic reactor and possibly in the anoxic reactor. In this way the poly-P bacteria sequester substrate from other bacteria in a state where these bacteria have very little energy available for substrate uptake.

3. This hypothesis explains the experimental fact that the extent of biological $\mathbf{P}$ removal from wastewater increases with increasing concentrations of soluble readily biodegradable organics in the sewage.

4. In mainstream processes where the $P$ is removed from the plant by surplus sludge production, the $\mathrm{P}$ removal is also increased by increasing the ratio of organic matter to $\mathrm{P}\left(\mathrm{BOD}_{5} / \mathrm{P}\right)$ in the sewage.

5. Nitrate and oxygen in the influent to the anaerobic reactor decreases biological $P$ removal through oxidation of the soluble readily biodegradable organics.

6. If simultaneous biological $\mathrm{N}$ and $\mathrm{P}$ removal is required, the ratio of Kjeldahl nitrogen to organic matter, TKN/COD, must be below 0.08 to 0.10 in order to obtain efficient $\mathrm{N}$ removal and by this low nitrate addition to the anaerobic reactor with the recycle sludge.

7. In sidestream processes where $P$ is removed by a combination of biological extraction of $P$ from the mainstream and chemical fixation of the extracted $P$ in a small concentrated sidestream, the P-removal efficiency appears unaffected by the $\mathrm{BOD}_{5} / \mathrm{P}$ ratio. 
8. Analysis of cations in sludge samples and cation removals from the mainstream in biological P-removal plants strongly indicate that phosphate precipitation may play a significant role: in some plants up to about $60 \%$ of the total $\mathrm{P}$ removal. The natural iron and aluminum content of the sewage seems important in order to obtain significant precipitation at $\mathrm{pH}$ values near 7 . It is also likely that a high phosphate concentration in the anaerobic reactor created by the biological $\mathrm{P}$ release stimulates precipitation. Furthermore, high calcium concentrations and slightly alkaline conditions, e.g., created by denitrification in biofilms, appear to promote precipitation.

9. There has been no research up to now on the analytical characterization of sludge from biological P-removal plants. It is impossible, therefore, to state how well present methods can differentiate between organic bound poly-P and precipitated phosphate.

10. The reactor design in biological P-removal plants is normally based on simple criteria like (aerobic) sludge age and detention times. However, future design will most likely be based on process models taking the specific composition of the wastewater into considerations. New models, which are in an early development phase, are based on the experimental fact that part of the biomass is poly-Paccumulating bacteria and the rest cannot accumulate poly-P.

11. Future models should also be able to quantify the extent of phosphate precipitation with cations in the sewage or cations conciously added to the plant.

12. Sidestream processes are able to reduce $P$ to a level of about $1 \mathrm{mg}$ of $P$ per liter under optimal conditions.

13. Mainstream processes can reduce, under optimal conditions, the $P$ to about $2 \mathrm{mg}$ of $\mathbf{P}$ per liter. With a small dosage of iron or aluminum salt, the effluent $P$ concentration can be reduced to about $1 \mathrm{mg}$ of $\mathrm{P}$ per liter.

14. Both sidestream and mainstream processes may require effluent filtration if the effluent $P$ concentration must comply with stringent limits. This is due to the relatively high $\mathrm{P}$ content in the sludge, about $4 \%$ of $\mathrm{P}$ in sidestream processes and 3.5 to $6 \%$ in mainstream processes.

\section{RESEARCH NEEDS}

In order to improve the basis for design and operation of biological P-removal plants, future research should deal with the following subjects:

1. Physical and biochemical characteristics of poly-P-accumulating bacteria: utilization of organic substrates, possible symbiose with nonpoly-P-accumulating bacteria, growth kinetics, effects of temperature and oxygen on growth rate, etc.

2. The type of phosphate precipitation products formed by cations in the sewage, their rate of formation, dissolution rates, and inhibition of crystal growth or dissolution by organic and inorganic substances in wastewater

3. Development of the understanding of basic biological and chemical P-removal processes in order to establish process design and analysis models (Such models must be able to quantify the effect of wastewater composition on the $\mathrm{P}$ removal. In this regard, a characterization method for the soluble low molecular organics in the sewage needs to be developed.)

4. Development of analytical techniques to characterize $P$ in both biological and inorganic sludge fractions

5. Development of both on-line techniques for measurement of $\mathrm{PO}_{4}-\mathrm{P}, \mathrm{NO}_{3}-\mathrm{N}$, and $\mathrm{NH}_{3}-\mathrm{N}$ in treatment plants and control strategies based on these parameters and other process parameters, e.g., the oxygen concentration in the aeration tank, to optimize $\mathrm{P}$ and nitrogen removal 


\section{REFERENCES}

1. Hansen, J. Aa., Tjell, J. C., and Lassen, R., Sanitary phosphorus recovery for agriculture, paper presented at Int. Conf. Harmless Disposal of Communal and Other Organic Wastes with Special Regard to Farm Land Application, Budapest, 1983.

2. Levin, G. V., Topol, G. J., Tarnay, A. G., and Samworth, R. B., Pilot plant tests of phosphate removal process, J. Water Pollut. Control Fed., 44, 1940, 1972.

3. Levin, G. V., Topol, G. J., and Tarnay, A. G., Operation of full scale biological phosphorus removal plant, J. Water Pollut. Control Fed., 44, 577, 1975.

4. Drnevich, R. F., Biological-Chemical Process for Removing Phosphorus at Reno/Sparks, NV, EPA600/2-79-007, U.S. Environmental Protection Agency, Cincinnati, Ohio, 1979.

5. Miyamoto-Mills, J., Larson, J., and Jenkins, D., Design and operation of a pilot-scale biological phosphate removal plant at Central Contra Costa Sanitary District, Water Sci. Technol.,15, 153, 1983.

6. Hong, S. N., Krichten, D. J., Kisenbauer, K. S. and Sell, R. L., A biological wastewater treatment system for nutrient removal, paper presented at Environmental Protection Agency Workshop on Biological Phosphorus Removal, Annapolis, Md., June 1982.

7. Deakyne, C. W., Design of an A/O process, paper presented at Environmental Protection Agency Workshop on Biological Phosphorus Removal in Municipal Wastewater Treatment, San Francisco, Calif., 1983.

8. Sell, R. L., Krichten, D. J., Noichl, O. J., and Hartzog, D. G., Low temperature biological phosphorus removal, paper presented at 54th Water Pollution Control Federation Conf., Detroit, 1981.

9. Rensink, J. H., Donker, H. J. G. W., and de Vries, H. P., Biological P-removal in domestic wastewater by the activated sludge process, in 5th European Sewage and Refuse Symp. EAS, Munich, Gesellschaft zur Forderung der Abwassertechnik, e.V., St. Augustin, 1981, 487.

10. Barnard, J. L., A review of biological phosphorus removal in the activated sludge process, Water $S$. A., 2, 136. 1976.

11. Barnard, J. L., Background to biological phosphorus removal, Water Sci. Technol., 15, 1, 1983.

12. Marais, G. v. R., Loewenthal, R. E., and Siebritz, I. P., Observations supporting phosphate removal by biological excess uptake. A review, Water Sci. Technol., 15, 15, 1983.

13. Siebritz, I. P., Ekama, G. A., and Marais, G. v. R., A parametric model for biological excess phosphorus removal, Water Sci. Technol., 15, 127, 1983.

14. Ekama, G. A., Siebritz, I. P., and Marais, G. v. R., Considerations in the process design of nutrient removal activated sludge processes, Water Sci. Technol., 15, 283, 1983.

15. Vestergaard, N. K., Biological phosphorus removal in the Biodenipho-process. A process model, unpublished report, Department of Environmental Engineering, Technical University of Denmark, 1984.

16. Bundgaard, E. Kristensen, G. H., and Arvin, E., Full scale experience with phosphorus removal in an alternating system, Water Sci. Technol., 15, 197, 1983.

17. Jones P. H., Treatment in municipal plants: innovation for removal of phosphorus, Water Res., 7 , $211,1973$.

18. Paepcke, B. H., Performance and operational aspects of biolgoical phosphate removal plants in South Africa, Water Sci. Technol., 15, 219, 1983.

19. Morgan, W. E. and Fruh, E. G., Phosphate incorporation in activated sludge, J. Water Pollut. Control Fed., 46, 2486, 1974.

20. Stall, T. R. and Sherrard, J. H., Effect of wastewater composition and cell residence time on phosphorus removal in activated sludge, J. Water Pollut. Control Fed., 48, 307, 1976.

21. Sutton, P. M. and Jank, B. E., Nutrient removal in suspended growth systems without chemical addition, J. Water Pollut. Control Fed., 52, (1), 98, 1980.

22. Fuhs, F. W. and Chen, M., Microbiological basis of phosphate removal in the activated sludge process for the treatment of wastewater, Microb. Ecol., 2, 119, 1975.

23. Harold, F. M., Inorganic polyphosphates in biology: structure, metabolism and function, Bacteriol. Rev., 30, 772, 1966.

24. Kualev, I. S., The Biochemistry of Inorganic Polyphosphates, John Wiley \& Sons, New York, N.Y., 1979.

25. Nicholls, H. A. and Osborn, D. W., Bacterial stress: prerequisite for biological removal of phosphorus, J. Water Pollut. Control Fed., 51(3), 557, 1979.

26. Nicholls, H. A., Kinetics of phosphorus transformations in aerobic and anaerobic environments, Prog. Water Technol., 10 (Suppl. 1), 89, 1979.

27. Buchan, L., Possible biological mechanism of biological removal, Water Sci. Technol., 15, 87, 1983.

28. Juni, E., Genetics and physiology of Acinetobacter, Annu. Rev. Microbiol., 32, 349, 1978.

29. Deinama, M. H., Habets, L. H. A., Scholten, J., Turkstra, E., and Webers, H. A. A. M., The accumulation of polyphosphate in Acinetobacter spp., FEMS Microbiol. Lett., 9, 275, 1980. 
30. Brodisch, K. E. U. and Joyner, S. J., The role of microorganisms other than Acinetobacter in biological phosphate removal in activated sludge processes, Water Sci. Technol., 15, 117, 1983.

31. Malnon, D., Meganek, M., Faup, G. M., and du Rostu, M., Biological phosphorus removal: study of the main parameters, paper presented at IAWPRC Workshop on Design and Operation of Large Wastewater Treatment Plants, Vienna, 1983, 19.

32. Fukase, T., Shibata, M., and Miyaji, Y., Studies on the mechanism of biological phosphorus removal, Jpn. J. Water Pollut. Res., 5(6), 309, 1982.

33. Shoda, M., Ohsumi, T., and Udaka, S., Screening for high phosphate accumulating bacteria, Agric. Biol. Chem., 44(2), 319, 1980.

34. Tamatami, H., Shoda, M., and Udaka, Growth and phosphate uptake of a high phosphate accumulating bacterium, Arthrobacter globiformis PAB-6 in continous culture, Biotechnol. Bioeng., 25, $1781,1983$.

35. Vacher, D., Connell, C. H., and Wells, W. N., Phosphate removal through municipal wastewater treatment at San Antonio, Texas, J. Water Pollut. Control Fed., 39, 750, 1968.

36. Wells, W. N., Differences in phosphate uptake rates exhibited by activated sludges, J. Water Pollut. Control Fed., 41,765, 1969.

37. Milbury, W. F., McCauly, D., and Hawthorne, C. H., Operation of conventional activated sludge for maximum phosphorus removal, J. Water Pollut. Control Fed., 43, 1890, 1971.

38. Widra, A., Metachromatic granules of microorganisms, J. Bacteriol., 78, 664, 1959.

39. Wood, H. G., Some reactions in which inorganic pyrophosphate replaces ATP and serves as a source of energy, Fed. Am. Soc. Exp. Biol. Fed. Proc., 36, 2197, 1977.

40. Winder, F. G. and Denneny, J. M., The metabolism of inorganic polyphosphate in mycobacterial, $I$. Gen. Microbiol., 17, 573, 1957.

41. Arvin, E., Kristensen, G.H., Exchange of organics, phosphate and cations between sludge and water in a biological phosphorus and nitrogen removal process, Water Sci. Technol., in press.

42. Siebritz, I. P., Ekama, G. A., and Marais, G. v. R., Biological Excess Phosphorus Removal in the Activated Sludge Process, Vols. 1, 2, and 3, Department of Civil Engineering Rondebosch, Rep. No. W 47, University of Cape Town, South Africa, 1983.

43. Potgieter, D. J. J. and Evans, B. W., Biochemical changes associated with luxury phosphate uptake in a modified Phoredox activated sludge system, Water Sci. Technol., 15, 105, 1983.

44. Levin, G. V. and Shapiro, J., Metabolic uptake of phosphorus by wastewater organisms, J. Water Pollut. Control Fed., 37, 800, 1965.

45. Boughton, W. H. et al., Metabolic factors affecting enhanced phosphorus uptake by activated sludge, Appl. Microbiol., 22, 571, 1971.

46. Carberry, J. B. and Tenney, M. W. Luxury uptake of phosphate by activated sludge, J. Water Pollut. Control Fed., 45, 2444, 1973.

47. Shapiro, J., Levin, G. V., and Zeag, H., Anoxically induced release of phosphate in wastewater treatment, J. Water Pollut. Control Fed., 39, 1810, 1967.

48. Arvin, E., Observations supporting phosphate removal by biologically mediated chemical precipitation, Water Sci. Technol., 15, 43, 1983.

49. Ferguson, J. F. and Horres, R. L., Two-step precipitation of calcium phosphate from wastewater, Prog. Water Technol., Suppl. 1, 157, 1979.

50. Ferguson, J. F., Jenkins, D., and Eastman, J., Calcium phosphate precipitation at slightly alkaline pH values, J. Water Pollut. Control Fed. 45, 620, 1973.

51. Zoltek, J., Phosphorus removal by orthophophate nucleation, J. Water Pollut. Control Fed., 46, 2498, 1974.

52. Kerdachi, D. A. and Roberts, M. R., Further developments in the understanding of phosphate removal at Umhlatuzana, paper presented at Southern Africa Branch of IWPG East London Conf., London 1983.

53. Kerdachi, D. A. and Roberts, M. R., Full scale phosphate removal experiences in the Umhlatuzana works at different sludge ages, Water Sci. Technol., 15, 261, 1983.

54. Arvin, E. and Kristensen, G. H., Effect of denitrification on the pH in biofilms, Water Sci. Technol., 14, 833, 1982.

55. Arvin, E. and Kristensen, G. H., Phosphate precipitation in bioflims and flocs, Water Sci. Technol., $15,65,1983$.

56. Riemer, M. and Harremoes, P., Multi-component diffusion in denitrifying biofilms, Prog. Water Technol., 10(5/6), 149, 1978.

57. Menar, A. B. and Jenkins, D., Calcium Phosphate Precipitation in Wastewater Treatment, EPA-R2-72-064 PB 216605, U.S. Environmental Protection Agency, 1972.

58. Hoffmann, R. J. and Marais, G. v. R., Phosphorus Removal in the Modified Activated Sludge Process, Department of Civil Engineering Rondebosch, Res. Rep. No. W 22, University of Cape Town, South Africa, 1977. 
59. Legeros, R. Z., Crystallographic Studies of the Carbonate Substitution in the Apatite Structure, Ph.D. thesis, Department of Basic Medical Sciences, New York University, 1967.

60. Legeros, R. Z., Shirra, W. P., Miravite, M. A., Legeros, J. P., Domingo, G. M., and Quirolgico, G. B., Amorphous calcium phosphates: synthetic and biological, Colloq. Int. C. N. R. S., 230, 105, 1975.

61. Legeros, R.Z., Taheri, M. H., Quirolgico, G. B., and Legeros, J. P., Formation and stability of apatites: effects of some cationic substituents, in Proc. 2nd Int. Congr. on Phosphorus Compounds, Boston, World Phosphate Rock Institute, Paris, 1980, 89.

62. Legeros, R. Z., Apatites in biological systems, Prog. Cryst. Growth Charact., 4, 1, 1981.

63. Bonel, G., Labarthe, J. C., and Vignoles, C., Contribution a l etude structurale des apatities carbonates de type B, Colloq. Int. C. N. R. S., 330, 117, 1975.

64. Montel, G., Bonel, G., Heughebaert, J. C., Trombe, J. C., and Rey, C., New concepts in the composition, crystallization and growth of the mineral component of calcified tissues, $J$. Cryst. Growth, $53,74,1981$.

65. Blumenthal, N. C., Betts, F. and Posner, A. S., Effect of carbonate and biological macromolecules on formation and properties of hydroxyapatite, Calcif. Tissue Res., 18, 81, 1975.

66. Blumenthal, N. C., Betts, F., and Posner, A. S., Stabilization of amorphous calcium phosphate by $\mathrm{Mg}$ and ATP, Calcif. Tissue Res., 3, 245, 1977.

67. Blumenthal, N. C., Betts, F., and Posner, A. S., Formation and structure of Ca-deficient hydroxyapatite, Calcif. Tissue Int., 33, 111, 1981.

68. Betts, F., Blumenthal, N. C., and Posner, A. S., Bone mineralization, J. Cryst. Growth, 53, 63, 1981.

69. Arends, J. and Ten Cate, J. M., Tooth enamel remineralization, J. Cryst. Growth, 53, 135, 1981.

70. Arvin, E. and Pedersen, G., A general equilibrium model for the precipitation of phosphate with iron and aluminum, Prog. Water Technol., 12(6), 283, 1980.

71. Arvin, E. and Skaarup, J., An equilibrium model for the removal of soluble phosphate with ferrous iron in simultaneous precipitation plants, Vatten, 35(2), 125, 1979.

72. Moreno, E. C. and Varughese, K., Crystal growth of calcium apatites from dilute solutions, J. Cryst. Growth, 53, 20, 1981.

73. Wells, W. N., Rate of phosphorus uptake by activated sludge, Water Sewage Works, Vol. 122.

74. Menar, A. B. and Jenkins, D., The fate of phosphorus in waste treatment processes: the enhanced removal of phosphate by activated sludge, in Proc. 24th Industrial Waste Conf., Purdue University, Lafayette, Indiana, 1969, 655.

75. Scalf, M. R., Pfeffer, F. M., Lively, L. D., Witherow, J. F., and Priesing, C. P., Phosphate removal at Baltimore, Maryland, ASCE J. Sanit. Eng. Div., 95, 817, 1969.

76. Whiterow, J. L., Phosphate removal by activated sludge, in Proc. 24th Industrial Waste Conf., Purdue University, Lafayette, Indiana, 1969, 1169.

77. Bargman, R. D., Betz, J. M., and Garber, W. F., Nitrogen-phosphate relationships and removals obtained by treatment processes at the Hyperion treatment plant, Adv. Water Pollut. Res., San Francisco and Hawaii, I-14/1-17, 1970.

78. Pitman, A. R., Venter, S. L. V., and Nicholls, H. A., Practical experience with biological phosphorus removal plants in Johannesburg, Water Sci. Technol., 15, 233, 1983.

79. Pitman, A. R., Optimization of the Modified Activated Sludge Process for Nutrient Removal, 61/1, City of Johannesburg, South Africa, 1983.

80. Furumai, H. and Ohgaki, S., Fractional composition of phosphorus in sediments related to release, Water Sci. Technol., 14, $215,1982$.

81. Lan, J. C., Benefield, L., and Randall, C. W., Phosphorus removal in the activated sludge process, Water Res., 17(9), 1193, 1983.

82. Rabinowitz, B. and Marais, G. v. R., Chemical and Biological Phosphorus Removal in the Activated Sludge Process, Department of Civil Engineering, Res. Rep. W 32, University of Cape Town, Rondebosch, South Africa, 1980.

83. Ebel, J. P., Colas, J., and Muller, S., Recherches cytochimiques sur les polyphosphates inorganiques contenus dans les organisms vivant. II. Mize au point de methodes de detection cytochimiques specifiques de polyphosphates, Exp. Cell. Res., 15, 28, 1958.

84. Ostrovskii, D. N., Sepetov, N. F., Reshetnyak, V. I., and Siberldina, L. A., Investigation of the localization of polyphosphates in cells of microorganisms by the by the method of high-resolution ${ }^{31}$ P-NMR-145.78 MHZ, Biochemistry, 45(3), 392, 1980.

85. Florentz, M. and Granger, P., Phosphorus 31 nuclear magnetic resonance of activated sludge use for the study of the biological removal of phosphates from wastewater, Environ. Technol. Lett., 4(1), 9, 1983.

86. Winder, F. G. and Denneny, J. M., Phosphorus metabolism of Mycobacteria: determination of phosphorus compounds in some Mycobacteria, J. Gen. Microbiol., 15, 1, 1956. 
87. Yall, I., Boughton, W. H., Knudsen, R. C., and Sinclair, N. A., Biological uptake of phosphorus by activated sludge, Appl. Microbiol., 20, 145, 1970.

88. Chang, S. C. and Jackson, M. L., Fractionation of soil phosphorus, Soil Sci., 84, 133, 1957.

89. Williams, J. D. H., Syers, J. K., and Walker, T. W., Fractionation of soil inorganic phosphate by a modification of Chang and Jackson's procedure, Soil Sci. Soc. Am. Proc., 31, 736, 1967.

90. Williams, J. D. H., Jaquet, J.-M., and Thomas, R.L., Forms of phosphorus in the surficial sediments of Lake Erie, J. Fish. Res. Bd. Can., 33, 413, 1976.

91. Hieltjes, A. H. M. and Lijklema, L., Fractionation of inorganic phosphates in calcareous sediments, J. Environ. Qual., 9(3), 405, 1980.

92. Calmano, W., Potentially bioavailable phosphorus in sediments of the Weser estuary, Environ. Technol. Lett., 2, 443, 1981.

93. Williams, J. D. H., Syers, J. K., Harris, R. F., and Armstrong, D. E., Fractionation of inorganic phosphate in calcareous lake sediments, Soil Sci. Soc. Am. Proc., 35, 250, 1971.

94. Barnard, J., Design considerations regarding phosphate removal in activated sludge plants, Water Sci. Technol., 15, 319, 1983.

95. Stensel, H. D., Biological nitrogen removal system design, paper presented at American Institute of Chem. Engineering 73rd Annu. Meet., Chicago, 1980.

96. Refling, D. R., Stensel, H. D., Burns, D. E., and Barnard, J. L., Facility modifications for nutrient removal using the Badenpho process, paper presented at Water Pollution Control Federation, 50th Annu. Conf., Philadelphia, 1977.

97. Stensel, H. D., Sakakibara, N., Refling, D. R., and Burdick, C. R., Performance of first U.S. fullscale Badenpho facility, paper presented at Environmental Protection Agency Int. Semin. on Control of Nutrients in Municipal Waste Effluents, 1980.

98. Gerber, A., Simpkins, M. J., Winter, C. T., and Scheepers, J. A., Biological Nutrient Removal from Wastewater Effluents: Performances Evaluation of the Phoredox and UCT Processes, Rep. C. Wat. 52, National Institute of Water Research, CSIR, Pretoria, South Africa, 1982.

99. Burdick, C. R., Refling, D. R., and Stensel, H. D., Advanced secondary treatment to achieve biological nutrient removal, paper presented at Water Pollution Control Federation, 53rd Annu. Conf., Las Vegas, Nev., 1980.

100. Peirano, L. E., Low cost phosphorus removal at Reno-Sparks, Nevada, J. Water Pollut. Control Fed., 49, 568, 1977.

101. Peirano, L. E., Henderson, D. B., Gonzales, J. G. M., and Davies, E. F., Full-scale experience with the Phostrip process, Water Sci. Technol., 15, 181, 1983.

102. Boller, M. A. and Kavanaugh, M. C., Contact filtration for additional removal of phosphorus in waste water treatment, Prog. Water Technol., 8(6), 203, 1977. 